\title{
36. A SYNTHESIS OF LEG 125 DRILLING OF SERPENTINE SEAMOUNTS ON THE MARIANA AND IZU-BONIN FOREARCS ${ }^{1}$
}

\author{
Patricia Fryer ${ }^{2}$
}

\begin{abstract}
The forearc region of the Mariana and Izu-Bonin convergent margin systems, the area between the trench axis and the active volcanic fronts, contains numerous large serpentine seamounts. These include either mud volcanoes, composed of unconsolidated serpentine mud flows that have entrained serpentinized ultramafic and other rock types, or horst blocks of serpentinized ultramafics, partially draped with unconsolidated serpentine slump deposits. Composite edifices form partially by uplift of blocks of metamorphosed lower crust or upper mantle, partially by subsequent or concomitant debris flows of serpentinized ultramafics, and typically display later serpentine mud flows. Tectonic processes on the forearc, particularly faulting, exert important controls over the distribution of serpentinite seamounts.

Drilling at Sites 778 and 779 on the flanks of Conical Seamount on the Mariana forearc retrieved silt- to clay-sized serpentine mud with blocks to small clasts of metamorphosed ultramafic and mafic rocks. The rheological properties of the Conical Seamount summit muds are consistent with mobilization of the serpentine at depth and surficial emplacement of the muds as fluid-charged flows. Mineralogy and bulk compositions of the mud samples from Conical Seamount suggest that three to six flow units are located on the flank of the seamount with possibly two at the summit. Similar studies of Torishima Forearc Seamount show one unit on the north flank (Site 783) and at most two on the west flank (Site 784). Variations in the lithology, mineralogy, and structure of the muds suggest differences in source material and possibly a combination of both debris deposits and mud flows at the two seamounts.

Unique pore fluids, both at the flank sites and at the summit on Conical Seamount, support the earlier findings from ALVIN submersible work of unusual vent and pore fluids suggested to derive from the subducted slab. The compositions of the pore waters from Torishima Forearc Seamount indicate fluids resulting almost solely from seawater interaction with peridotite at low temperatures.

Peridotite clasts entrained in the serpentine muds of the seamounts trace a sequence of tectonic and magma genesis events: (1) initial formation of the peridotite under high-temperature asthenospheric conditions, such as are prevalent in the upper mantle of most ophiolite complexes (either at mid-ocean ridges or in island-arc regimes) followed by remelting and possible infusion of the peridotite with a fluid phase accompanied by a period of high-temperature, low-stress deformation of the peridotite, either precursory to initiation of convergence, or during proto-arc formation; (2) development of ductile shear zones coeval with a protracted period of retrograde metamorphism that accompanied subduction; and (3) brittle failure of the metamorphosed peridotite.

Mafic clasts recovered in the serpentine muds of Conical Seamount comprise five geochemical groups: island-arc tholeiite, boninite, mid-ocean-ridge-like basalt, and basalt intermediate between island-arc tholeiite and mid-ocean-ridge basalt. The presence of basalt with mid-ocean-ridge basalt composition requires a reevaluation of existing theories of the formation of this part of the Mariana forearc. Metamorphism of the mafic samples took place principally under low-temperature and low-pressure conditions. The mafic rocks from Conical Seamount that contain blueschist-facies metamorphic minerals are considered to have derived from a low-temperature $\left(150^{\circ}-250^{\circ} \mathrm{C}\right)$ but deep $(13-18 \mathrm{~km})$ portion of the forearc. The grade of metamorphism of the Torishima Forearc Seamount samples is prehnite-actinolite facies, which requires a low-temperature/low-pressure regime $\left(200^{\circ}-\right.$ $300^{\circ} \mathrm{C}$ and $0-6 \mathrm{~km}$ deep).

Numerous examples of sedimentary serpentinite deposits exposed on land are similar to the deposits forming on Conical and represented by the older deposits at Torishima Forearc Seamount. Conical Seamount may represent a type locality for the study of in-situ formation of sedimentary serpentinite bodies that originated by a combination of protrusion and seafloor mud volcanism.
\end{abstract}

\section{INTRODUCTION}

\section{Geologic Setting}

The Mariana/Izu-Bonin convergent margins of the western Pacific currently comprise a complex series of intraoceanic arcs and backarc basins that formed since the start of westward subduction of Pacific lithosphere during the Eocene (Fig. 1). Convergence rates are between 8 and $10 \mathrm{~cm} / \mathrm{yr}$ to the northwest. The Pacific Plate dips at an angle of about $12^{\circ}$ at shallow depths, rapidly steepening to vertical in some places below about $100 \mathrm{~km}$.

Early investigators of the Mariana and Izu-Bonin convergent margin systems provided a variety of evolutionary schemes to account for the current configuration of the major tectonic elements of the region. Uyeda and Ben-Avraham (1972) suggested that the Philippine

'Fryer, P., Pearce, J. A., Stokking, L. B., et al., 1992. Proc. ODP, Sci. Results, 125: College Station, TX (Ocean Drilling Program).

2Planetary Geosciences, Department of Geology and Geophysics, School of Ocean and Earth Science and Technology, University of Hawaii, 2525 Correa Rd., Honolulu, HI 96822, U.S.A.
Sea Plate formed as a trapped piece of Kula/Pacific Plate crust when reorientation of spreading occurred in the Pacific approximately $42 \mathrm{Ma}$. They further suggested that the subduction was initiated along a former transform fault offset some $1500 \mathrm{~km}$ and oriented roughly north-south between two east-west spreading center segments of the Pacific/Kula mid-ocean ridge. Shih (1980) provided magnetics evidence that confirmed the entrapment hypothesis, but noted that the West Philippine Basin drifted north about $15^{\circ}$ to $20^{\circ}$ and underwent clockwise rotation of about $50^{\circ}$ to $70^{\circ}$ since initial formation at about $40 \mathrm{Ma}$. Klein and Kobayashi (1980) and Lewis et al. (1982) later suggested that the northern portion of the Philippine Sea Plate, from the Oki-Daito Ridge to the Palau Kyushu Ridge and the intervening basins, formed as a consequence of southward convergence, arc formation, and episodes of backarc rifting. They suggested that this region was moved northward as an integral part of the Philippine Plate during the translation/rotation episode. From about 21 to $15 \mathrm{Ma}$ the Parece Vela and Shikoku basins were opening, and the separation of the Mariana/Izu-Bonin arcs from the Palau-Kyushu remnant arc occurred (Scott et al., 1980). The opening of the Mariana backarc basin began at about $6.5 \mathrm{Ma}$ (Hussong and Uyeda, 1981), and the 


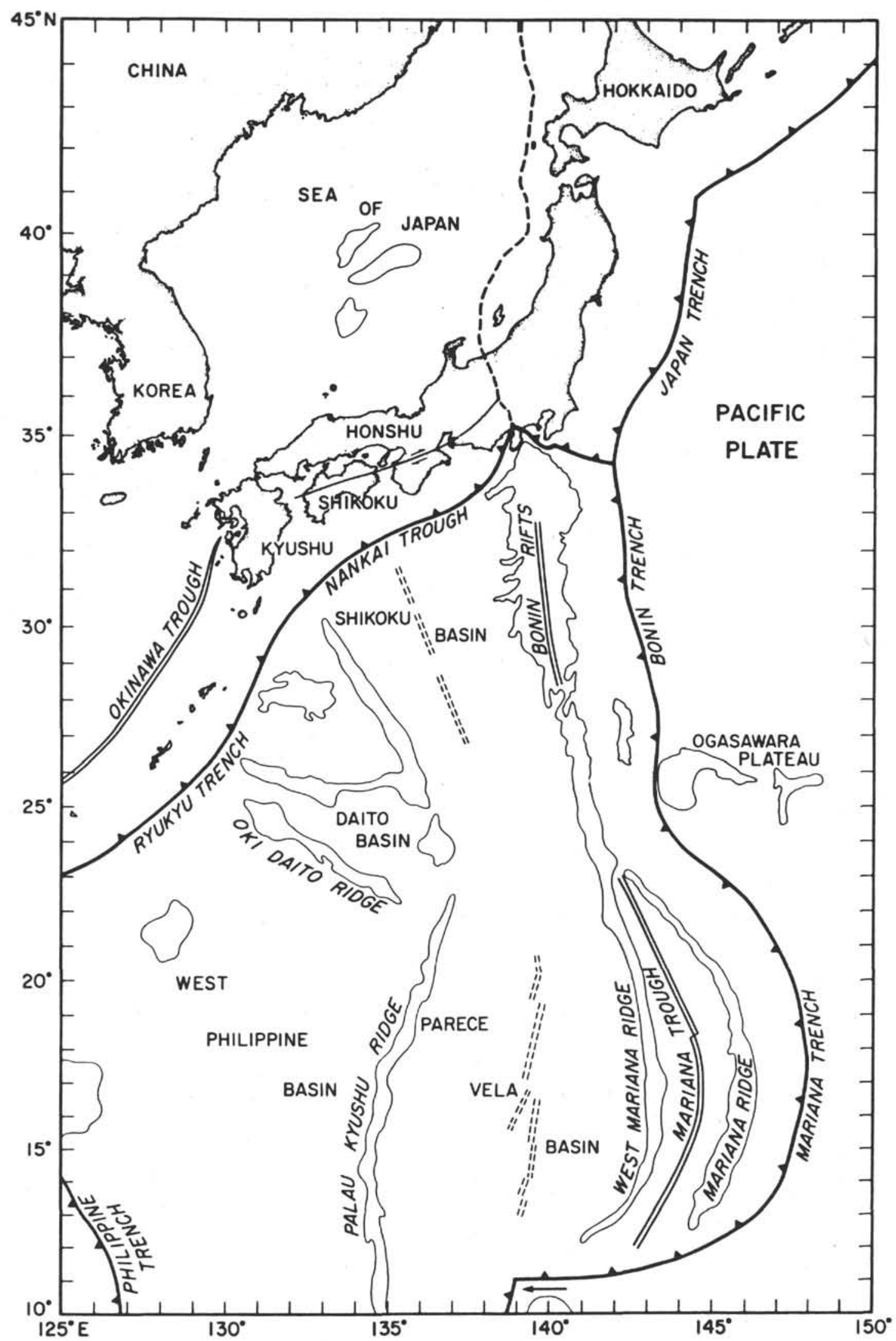

Figure 1. Bathymetry and geologic features in the Philippine Sea region. Basins and ridges are outlined by the 4-km bathymetric contour, except for the Izu-Bonin arc, West Mariana Ridge, and Mariana arc, which are outlined by the 3-km contour. Barbed lines locate axes of trenches; medium double lines locate active spreading centers; dashed double lines locate relict spreading centers; single dashed line is a proposed new plate boundary. 
initiation of the Izu-Bonin rifts probably began as recently as $1 \mathrm{Ma}$ (Brown and Taylor, 1988).

The nature of the forearc regions (those areas between the volcanic front and the axis of the trench) have provoked considerable debate over the last two decades. The recognition that both accretionary and erosional processes can be active in supra-subduction zones and can produce vastly different types of forearc regions is a major advance in our understanding of the evolution of forearc terranes (Karig, 1971; Hussong and Uyeda, 1981; Karig and Ranken, 1983; Fryer and Fryer, 1987). Both the Mariana and Izu-Bonin forearcs appear to be primarily erosional. No large accretionary wedge of sediments has been noted in either of these forearc regions and the results of studies of rocks collected from these areas indicate that they formed primarily of arc magmas (Skornyakova and Lipkina, 1976; Dietrich et al., 1978; Meijer, 1980; Wood et al., 1981; Bloomer 1982; Beccaluva et al., 1980; Bloomer and Hawkins, 1983; Honza and Tamaki, 1985; Ishii, 1985; Fryer et al., 1985; Fryer and Fryer, 1987; Johnson and Fryer, 1987; Saboda et al., 1987; Johnson and Fryer, 1988). Even in the deepest exposures of the inner trench walls, the predominant rock type is an island-arc basalt. Only small volumes of alkalic basalts, presumed to be off-scraped fragments of oceanic islands, had been noted in the samples recovered close to the inner wall of the Mariana Trench (Bloomer and Hawkins, 1983). On the basis of these observations, it was suggested that the forearcs had been formed by arc volcanism and that the arc volcanics were exposed in the inner trench wall by tectonic erosion (Bloomer, 1982). Recent dredge samples from the mid-region of the Mariana forearc suggest a different evolution. Basalts with trace element signatures of mid-ocean-ridge basalt (MORB) were collected from a deep fault scarp nearly $70 \mathrm{~km}$ from the trench axis (Johnson and Fryer, 1988), and radiolarians yielding an age of 130 Ma were identified from cherts in the same dredge hauls (Johnson et al., 1991). The occurrence of MORB and Cretaceous fossils in these dredges requires an adjustment of the existing models of evolution of the forearc regions.

In addition to the arc volcanics, numerous exposures of ultramafic rocks are found in the outer portions of both the Mariana and the Izu-Bonin forearcs (Bloomer, 1982; Bloomer and Hawkins, 1987; Fryer et al., 1985; Ishii, 1985; Fryer and Fryer, 1987). Large seamounts of serpentinite are forming over a zone approximately 100 $\mathrm{km}$ wide on the Mariana forearc, particularly between $17^{\circ}$ and $20^{\circ} \mathrm{N}$ (Hussong and Fryer, 1985; Fryer et al., 1985; Fryer and Fryer, 1987) (Fig. 2), and older, sediment draped seamounts are exposed on a narrow ridge on the inner trench wall of the Izu-Bonin system within $50 \mathrm{~km}$ of the trench axis (Honza and Tamaki, 1885; Ishii, 1985; Fryer and Fryer, 1987) (Fig. 3). The Mariana seamounts were first suggested to be serpentinite diapirs by Hussong and Fryer (1981) and later described in detail by Bloomer (1982). Their origin is related to two types of processes. The seamounts vary from horst blocks of uplifted metamorphosed ultramafics to edifices similar to mud volcanoes, but far larger. These seamounts reach maximum dimensions of about 30 $\mathrm{km}$ in diameter and $2000 \mathrm{~m}$ high.

The active eruption of serpentine muds to form large edifices, the composition of associated fluids seeping through the vent systems, and the composition of chimney structures associated with the seeps were previously unknown in the ocean basins (Fryer and Fryer, 1987; Haggerty, 1987a, 1987b; Leg 125 Shipboard Scientific Party, 1989. 1990; Fryer, Pearce, Stokking, et al., 1990). The metamorphism and deformation of the forearc wedge to produce the serpentine and structures characteristic of the serpentine seamounts records the history of evolution of the forearc region.

\section{Drilling Objectives and Previous Work}

The principal objectives of Leg 125 were to study two poorly understood aspects of evolution of forearc terranes in an active intraoceanic arc setting: (1) the origin and evolution of forearc terranes and (2) the dewatering of the subducted Pacific oceanic litho- sphere during subduction. The first of these objectives was addressed by a series of drill sites through the sediments and into the basement of the Mariana and Izu-Bonin forearcs, including one serpentine seamount on each of these forearc regions. Conical Seamount on the Mariana forearc region (Fig. 2) and Torishima Forearc Seamount on the Izu-Bonin forearc region (Fig. 3) were the targets for the seamount drilling. The second of these objectives was addressed indirectly through studies of forearc basement crust and directly through analyses of serpentine muds, pore fluids, chemical precipitates, and metamorphic rocks from serpentine seamounts. The serpentine seamounts provide an opportunity to study deep-seated processes of supra-subduction zone metamorphism and fluid flux. The unconsolidated fine-grained serpentine that protrudes through Conical Seamount apparently entrains country rock from the walls of its conduit. The rising serpentine thus samples rock types from deeper levels than can be reached even by deep-sea drilling techniques.

The specific objectives of drilling at Site 780 on the summit of Conical Seamount (Fig. 4) on the Mariana forearc focus on (1) emplacement mechanisms of the serpentine muds, (2) the nature of serpentinization processes within the seamount, and (3) the interactions between fluids and rock within the conduit of the edifice. The mechanical properties of the serpentine muds near the conduit were investigated. The composition of the associated fluids and entrained rocks were determined. The compositional and physical variability of the rising serpentine were studied. Although these immediate objectives are site specific, they apply to the understanding of several larger questions. The two most obvious of these questions concern the relationship of formation of serpentine mud volcanoes in forearc regions to the general history of convergent margin processes, and the geochemical mass balance of the subduction process.

The summit site lies at a depth of about $3100 \mathrm{~m}$ (Fig. 4). Previous work, particularly bottom photography and $A L V I N$ dive observations at the summit, revealed recent flows of unconsolidated sedimentary serpentinite that apparently emanate from, and mantle, the summit region (Fryer et al., 1987; Fryer et al., 1990). There is strong evidence to suggest that the rising serpentinite mud entrains deep-seated fluids as it rises. Results of $A L V I N$ dive studies of the summit of the seamount showed that fluids are actively seeping from carbonate and silicate chimneys and related structures on the southwest side of the summit (Fryer et al., 1987, Haggerty, 1987a, 1987b; Fryer et al., 1990). At no other locality on the seamount were active seeps or chimney structures observed. Studies of the composition of fluids collected with $A L V I N$ from an actively seeping chimney structure on Conical Seamount revealed high $\mathrm{pH}(9.28$ vs. 7.72 for ambient seawater), high alkalinity (5.53 vs. $2.41 \mathrm{meq} / \mathrm{L})$, and enrichment in $\mathrm{CH}_{4}(1000$ vs. $2.1 \mathrm{nM}), \mathrm{SiO}_{2}$ (0.75 vs. $\left.0.12 \mathrm{mM}\right), \mathrm{SO}_{4}(30.4$ vs. 28.6 $\mathrm{mM}$ ), and $\mathrm{H}_{2} \mathrm{~S}$ (2.1 $\mu \mathrm{M}$ vs. not detected) (Fryer et al., 1990). The $\mathrm{CH}_{4}$ and $\mathrm{H}_{2} \mathrm{~S}$ detected in the vent fluids were particularly interesting. The Mariana forearc has only a small volume of sedimentary substrate (Hussong and Uyeda, 1981), with organic carbon contents typically less than $0.3 \%$ (Schorno, 1981). Thus, the methane and sulfide in the Mariana vent fluids are unlikely to have formed by the biogenic processes associated with accretionary complexes, such as described by Kulm et al. (1986). Rather, they were probably generated during serpentinization reactions. Overall, the chemical analyses of these fluids imply that deep-seated serpentinization processes, juvenile mantle fluids, interaction of seawater with crustal rocks, and interactions of seawater with the surficial serpentinite may all contribute to the composition of the fluids.

Trace element and stable isotopic compositions of the carbonate chimney materials from Conical Seamount also are consistent with deposition from serpentinite-related fluids that contained components from either the forearc mantle or the subducted slab or both (Haggerty, 1987b). Haggerty (1987b) noted that compared with fracture-zone carbonates thought to have a dominantly seawater origin, for example, Mariana aragonite is depleted in $\mathrm{Sr}$ (Mariana samples = $7000-9400 \mathrm{ppm}$; fracture zone aragonite $=9500-11,600 \mathrm{ppm})$, is 


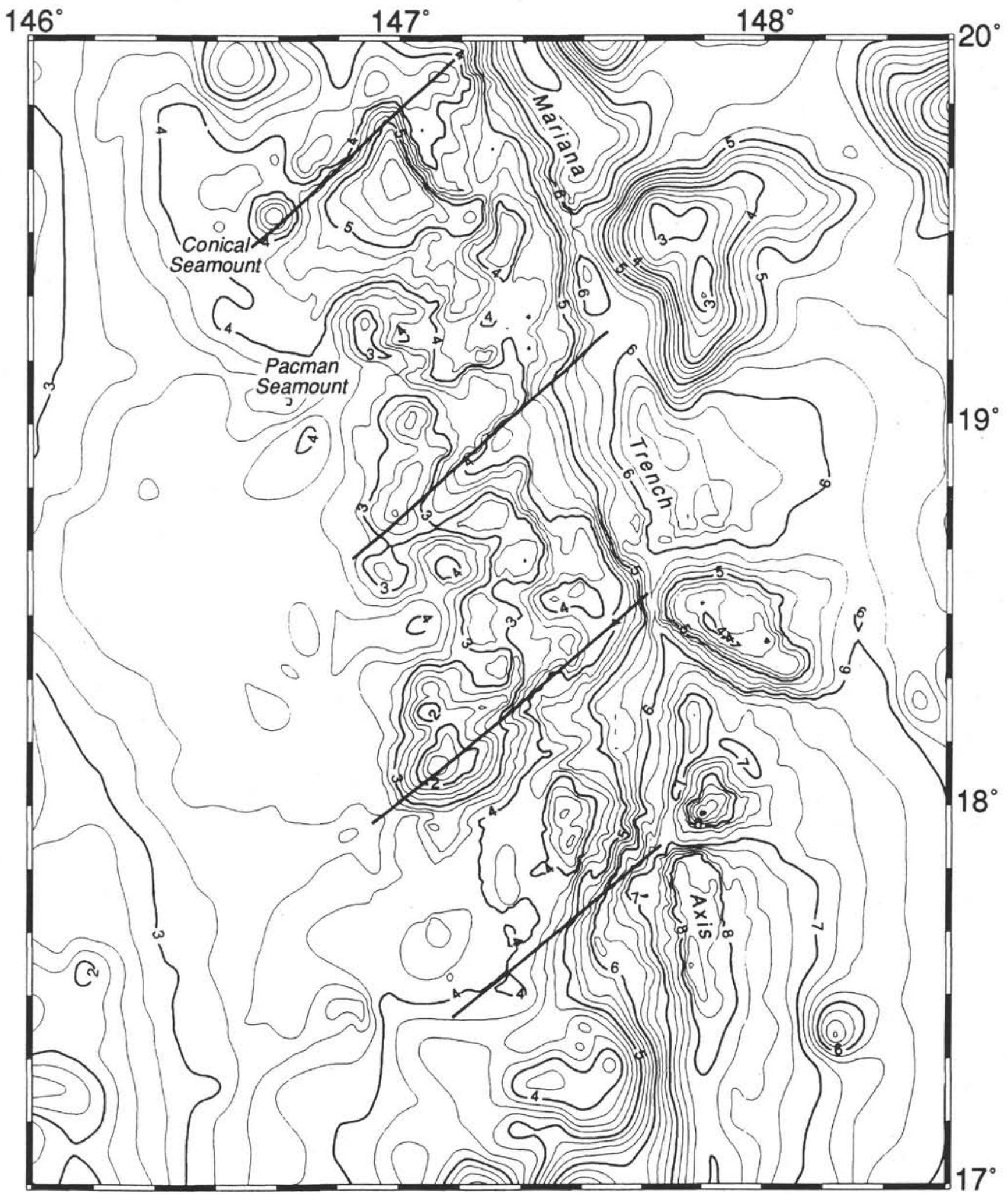

Figure 2. Bathymetry (in kilometers) of the central Mariana arc from SeaMARC II, seismic reflection, and U.S. Navy SASS data. Contours are in 250-m intervals. 

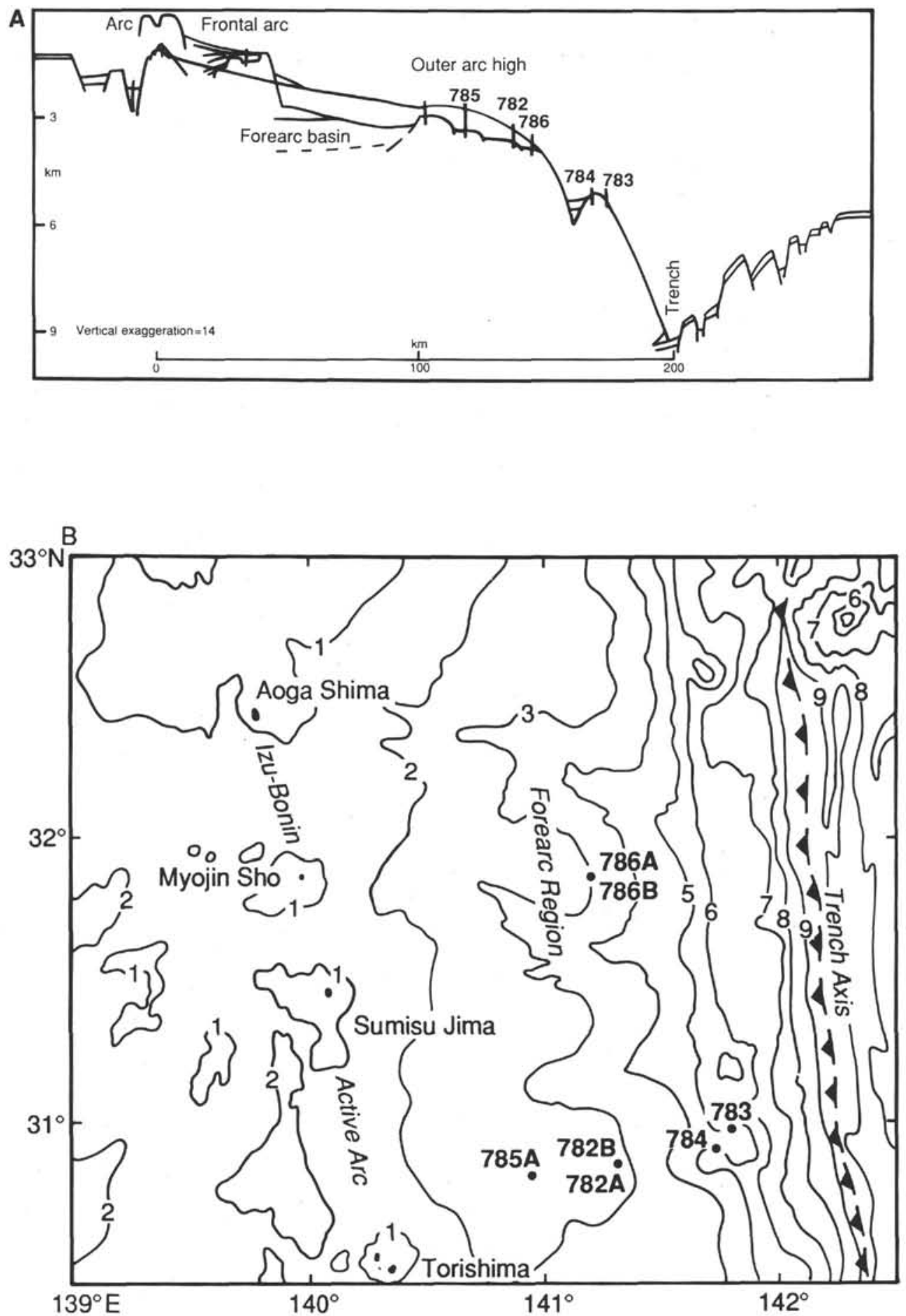

Figure 3. Schematic cross section (A) of the Izu-Bonin forearc showing the morphology of the frontal arc (both adjacent to the arc volcanoes) as in the upper trace, and in intervolcanic regions as in the lower trace), the outer-arc high (locations of Sites 782, 785, and 786), and a sediment-draped ridge along the inner wall of the trench (locations of Sites 783 and 784). Bathymetry (B) of the Izu-Bonin forearc showing the location of the Leg 125 drill sites. Contours are in 1000-m intervals.

enriched in $\mathrm{Mg}$ (Mariana $=750-6300 \mathrm{ppm}$, fracture zone $<300 \mathrm{ppm})$, and has a significantly lighter carbon isotopic signature (Mariana $=$ -1.2 to $-21.2 \mathrm{o} / \mathrm{oo}$, fracture zone $=+0.03$ to $+1.12 \mathrm{o} / \mathrm{oo})$ and a heavier oxygen isotopic signature (Mariana $=+5.1$ to $+7.60 / 00$, fracture zone $=+3.16$ to $+4.87 \mathrm{o} / \mathrm{oo}$ ). The fluids associated with these chimney materials are influenced by interactions between ultramafic rock and seawater. However, there must be an additional source for the fluids.
The trace element and isotopic compositions observed are consistent with derivation of the additional fluids from dewatering of subducted oceanic lithosphere, or from the mantle underlying the forearc, or both (Haggerty, 1987a; 1987b). Detailed sampling at depth within the serpentinite body, it was hoped, would constrain either the nature of the shallow level reactions influencing the fluid composition or the possible sources of the fluids. Results of the shipboard and shore- 
A

$146^{\circ} 40^{\prime} \mathrm{E}$

।

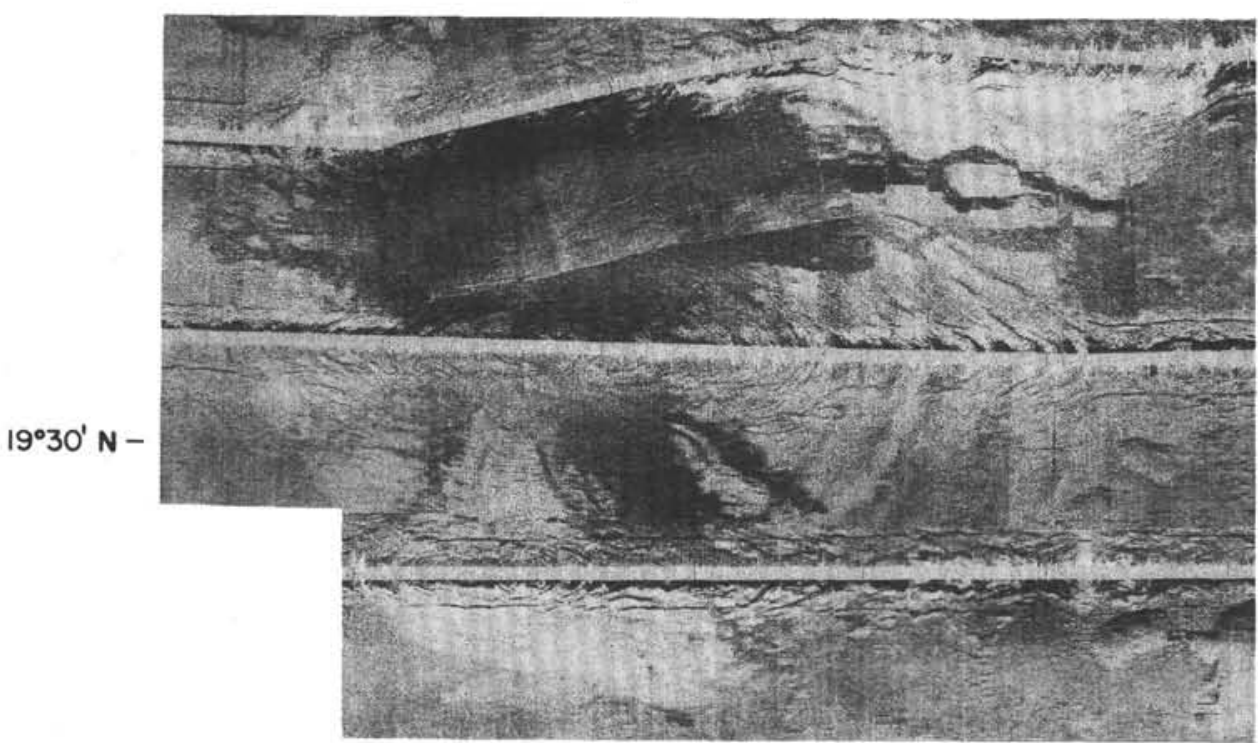

$-19^{\circ} 30^{\prime} \mathrm{N}$

0

$10 \mathrm{KM}$

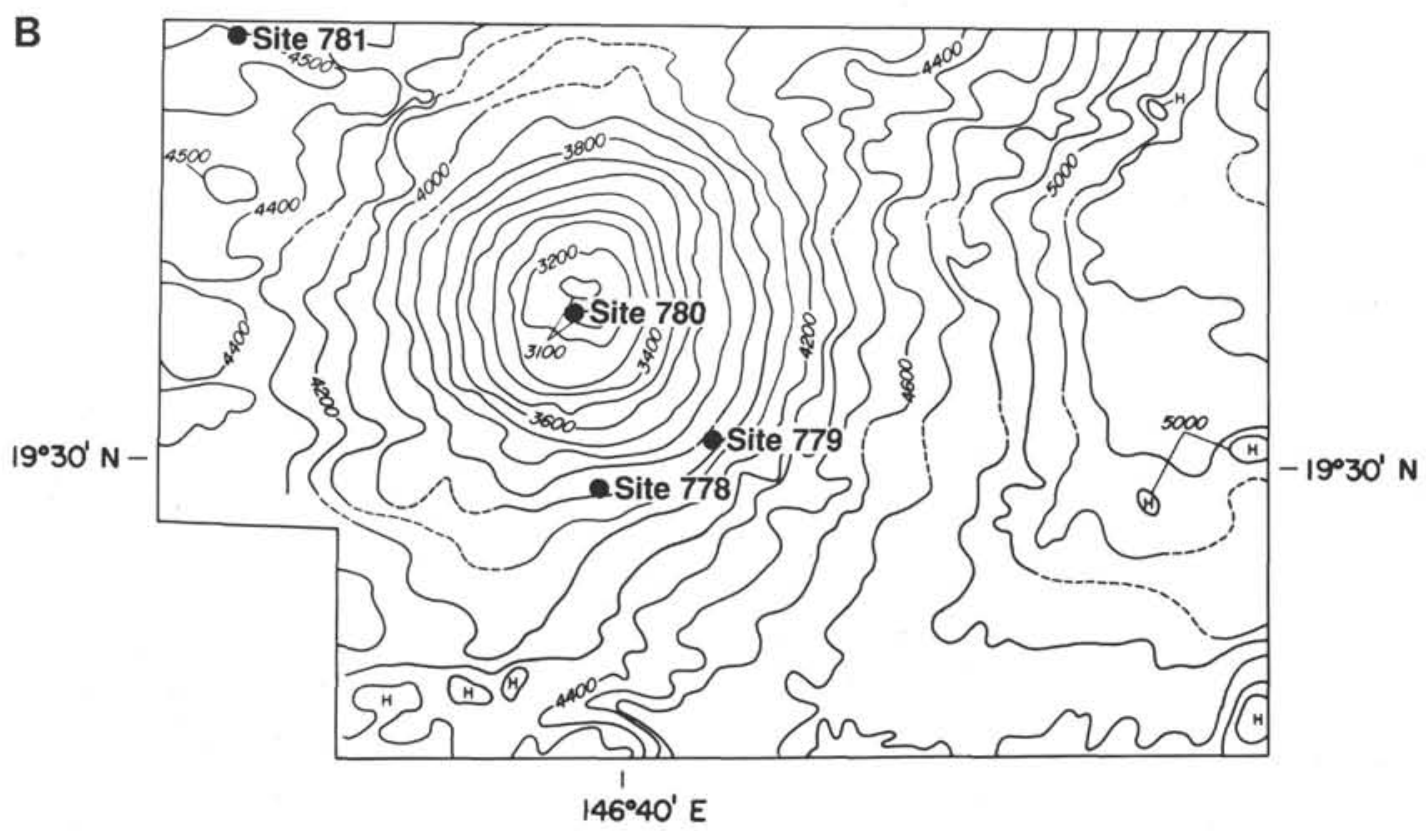

Figure 4. SeaMARC II side-scanning sonar image (top) and bathymetry (bottom) of Conical Seamount showing locations of Leg 125 Sites 778 through 781 . Contours are in 100-m intervals. Side-scanning image shows regions of high backscatter as dark areas.

based studies of the pore fluids from Leg 125 are reported in Haggerty and Chadhuri (this volume), Haggerty and Fischer (this volume), Mottl (this volume), and Mottl and Alt (this volume).

The objectives of drilling the flank Sites 778 and 779 on Conical Seamount (Fig. 4) were to determine (1) the internal stratigraphy and the extrusion and deformation history of the serpentine muds comprising the seamount, (2) the chemical effects of serpentinization on the lithospheric substrate of the region (through examination of the clasts of igneous and metamorphic rocks entrained in the muds) as well as on the muds that comprise the seamount, and (3) origin of the fluids associated with the serpentine. We also hoped that drilling would penetrate at least one of the serpentine flow units and enable us to study the lithosphere underlying the seamount so as to provide a basis for comparing of the metamorphism of lithospheric blocks entrained in 
the mud flows with underlying country rock. The nature of the serpentinization of the samples within the seamount was to be investigated by examining the mineralogy and composition of the clasts and matrix of the flows.

At both the summit and the flank sites, the protolith of the clasts entrained within the serpentine flows was to be investigated through studies of the mineralogy, texture, deformation, and physical properties of the clasts of rock entrained within the serpentine muds. The metamorphic history of the protolith was to be determined through mineralogical and geochemical studies of the clasts.

Torishima Forearc Seamount is located on the lower forearc terrace of the Izu-Bonin inner trench wall (Fig. 5). Studies of the structure and gravity characteristics of the seamount by Horine et al. (1990) indicate that the seamount is mantled by a relatively thin (less than $1 \mathrm{~km}$ thick) sequence that lacks internal reflectors. Dredging and coring of the summit and upper slopes of this seamount showed that the capping material is composed of serpentine muds and clasts of peridotite (Ishii, 1985; Ishii et al., 1985). This sequence is underlain by a seismically reflective region, presumably a block of serpentinized peridotite (Horine et al., 1990). Gravity data from the studies of the Izu-Bonin forearc indicate that a low-density zone, presumably serpentinized peridotite, underlies the Torishima Forearc Seamount, and indeed all of the outer forearc ridge of the Izu-Bonin inner trench wall. The gravity model proposed by Horine et al. (1990) indicates that the low-density material extends to the decollement. This modeling is consistent with earlier theoretical calculations proposed by Fryer and Fryer (1987). The origin of the outer forearc ridge along the inner wall of the Izu-Bonin trench was suggested by Fryer and Fryer (1987) to be related to hydration and associated uplift of the outer portion of the forearc wedge. They suggested that localized regions of greater hydration might account for the localized highs ("seamounts") that are situated along the crest of the Izu-Bonin outer

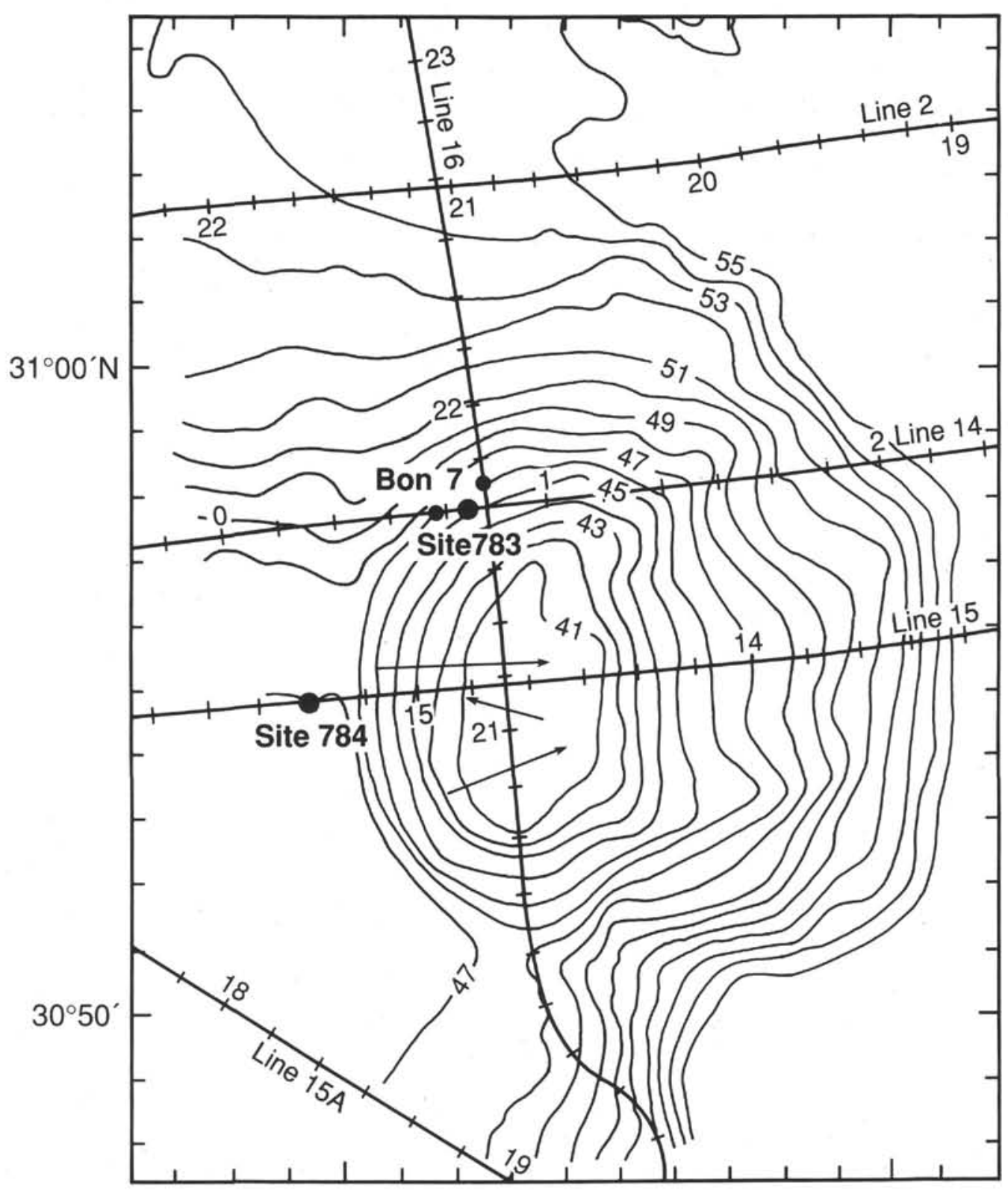

Figure 5. Bathymetry of Torishima Forearc Seamount showing locations of Leg 125 Sites 783 and 784 and dredges (arrows). Contours are in 100-m intervals. 
forearc ridge. The studies of Horine et al. (1990) imply that the kilometer-thick cap on Torishima Forearc Seamount is composed of serpentine mud flows, similar to those of Conical Seamount, suggesting that a higher degree of hydration of the forearc mantle is associated with Torishima Forearc Seamount. Their work suggests that Torishima Forearc Seamount is a composite edifice comprised of an uplifted block of low-density, presumably hydrated, forearc mantle through which have erupted serpentine mud flows containing entrained clasts.

Site 783, the first of two sites drilled on the flanks of the seamount, was on the northern, mid-flank portion of the seamount at $30^{\circ} 57.86^{\prime} \mathrm{N}$, $140^{\circ} 47.27^{\prime} \mathrm{E}$, at a depth of about $4650 \mathrm{~m}$ (Fig. 5). The objectives of drilling at this site were (1) to determine the nature of sediments in the outermost forearc region; (2) to study the sedimentary sequences on the flank of the seamount, and, hence, to constrain the regional tectonic history of the ridge upon which the seamount is located, the age of the seamount, and the mode of emplacement of the seamount; (3) to study the composition and structure of basement underlying the sedimentary column in order to determine whether the seamount is a block of up-thrown lower crustal material or an older, tectonized analog of Conical Seamount; and (4) to determine the composition of interstitial waters present in the sediments.

Site 784 is approximately $7 \mathrm{~km}$ south-southwest of Site 783 (Fig. 5). The choice of location was based on seismic data collected during the survey of the seamount prior to occupation of Site 783, which indicated that an eastward dipping fault plane underlay the west flank of the seamount. Site 784 was chosen at $30^{\circ} 54.49^{\prime} \mathrm{N}, 140^{\circ} 44.27^{\prime} \mathrm{E}$, at a depth of about $910 \mathrm{~m}$ overlying the fault trace. The objectives of Site 784 are similar to those of Site 783 , but in addition the drilling was intended (1) to establish the age and mode of emplacement of the seamount through a study of possible interlayered pelagic sediments and serpentinite flows; (2) to reveal the structure and composition of the basement of the seamount; and (3) to permit, if possible, correlation of strata between Sites 784 and 783 .

\section{RESULTS OF LEG 125 DRILLING}

\section{Conical Seamount Summit}

\section{Summit Lithology}

At Site 780, on the summit of Conical Seamount, four holes were drilled within $163 \mathrm{~m}$ of each other (Fig. 6). The stratigraphic section at Site 780 , based on shipboard observations, is divided into two lithologic units (Fryer, Pearce, Stokking, et al., 1990) (Fig. 7A-C). Lithologic Unit I, 0 to 3.5 meters below seafloor (mbsf) in Sections $125-780 \mathrm{~A}-1 \mathrm{H}-1$ to $125-780 \mathrm{~A}-1 \mathrm{H}-\mathrm{CC}$; 0 to $18.2 \mathrm{mbsf}$ in Sections $125-780$ B-1R-1 to $125-780$ B-2R-CC; 0 to 14.0 mbsf in Sections 125-780C-1R-1 to 125-780C-2R-CC; and 0 to 15.4 mbsf in Sections 125-780D-1X-1 to $125-780 \mathrm{D}-3 \mathrm{X}-\mathrm{CC}$, is composed of sand-, silt-, or clay-sized serpentine $(55 \%)$, clay $(20 \%)$, opaque minerals $(20 \%)$, epidote/zoisite (5\%), and chlorite (trace). Most of the serpentine mud matrix also contains authigenic aragonite needles. No biogenic components are present in the serpentine mud; however, Unit I does contain some sediments having an obvious biogenic and detrital component that are intercalated between the serpentine mud intervals. These are foraminifer-bearing serpentine silts and clays that contain serpentine $(68 \%-76 \%)$, opaque minerals $(5 \%-10 \%)$, aragonite $(5 \%-$ $6 \%)$, foraminifers $(10 \%)$, nannofossils $(1 \%-2 \%)$, spicules $(0 \%-3 \%)$, silicoflagellates $(1 \%-2 \%)$, diatoms $(1 \%)$, and radiolarians $(0 \%-1 \%)$. A Holocene (?)-middle Pleistocene (?) age range is suggested for Unit I based on the microfossils. Filamentous opaque debris interpreted as remnants of bacterial mats are found in smear slides throughout this unit. Intercalations of these sediments containing pelagic detritus indicate periods of multiple exposure of serpentine at the seafloor. On the basis of similar lithologies and biostratigraphic criteria, this unit correlates with Unit I at Sites 778 and 779, described later.
Unit II at the summit sites extends from 14.0 to $163.5 \mathrm{mbsf}$ in Sections $125-780$ C-3R-1 to $125-780$ C-18R-CC, and from 15.4 to 32.4 mbsf in Sections 125-780D-4X-1 to 125-780D-7X-CC. The unit is a serpentine mud with clasts composed dominantly of serpentinized harzburgite and subordinate serpentinized dunite. The matrix is composed of silty clay-sized serpentine $(70 \%-99 \%)$, opaque minerals $(1 \%-15 \%)$, clay $(0 \%-10 \%)$, epidote/zoisite $(0 \%-5 \%)$, thulite (?) $(0 \%$-trace), chlorite $(0 \%-5 \%)$, with up to $2 \%$ micrite and garnet, and is, in part, highly deformed by drilling.

Mineralogical differences between the serpentine mud samples from the summit holes, determined by shore-based analysis (Fryer and Mottl, this volume), and subtle differences between pore-fluid compositions (Mottl, this volume), suggest a subtle spatial variation near the conduit. Only two of the summit holes (780C and 780D) penetrated to significant depth. An increase in the diversity of the lithology of the muds, based on the shipboard descriptions of the smear slides, begins in Core 125-780C-2R at a depth of about 100 mbsf. It is possible that this change in lithology marks a boundary between two compositional units within the hole (Fryer and Mottl, this volume). Members of the rare sjogrenite group (hydroxide carbonate hydrates) and certain other rare secondary phases are present in the muds from the summit holes (Fryer and Mottl, this volume; Heling and Schwarz, this volume), as well as from the flank sites (described below). The presence of sjogrenite group minerals implies that the alteration of the serpentine muds to form the minerals must be taking place in situ in the seamount. The unusual pore waters, suggested to have been derived from a deep source (Fryer et al., 1990; Mottl, this volume; Haggerty and Chadhuri; this volume; Haggerty and Fisher, this volume; Mottl and Alt, this volume) associated with the rising serpentine muds, likely maintain the stability conditions of these minerals within the mud flows. The formation of one of the sjogrenite group minerals, iowaite $\left(\mathrm{Mg}_{4} \mathrm{Fe}(\mathrm{OH})_{8} \mathrm{OCl} x \mathrm{H}_{2} \mathrm{O}\right)$, requires interaction with seawater to provide the chloride necessary for its formation (Heling and Schwarz, this volume).

\section{Summit Structures and Physical Characteristics}

The serpentine mud matrix recovered from Site 780 lacks any sheared foliation fabrics. Textures, apparently derived from detrital processes (clasts scattered in matrix and subhorizontal lamination) are common in the upper parts of the cores. Matrix recovery was generally poor in the lower parts of the holes, but the approximately $3 \mathrm{~m}$ recovered from a depth of $30 \mathrm{mbsf}$ at the bottom of Hole 780D shows clast-in-matrix textures, that lack shear foliation and exhibit faint subhorizontal boundaries between muds of slightly different color. These undeformed fabrics may be typical of textures of the serpentine mud deposits near the conduit.

Tests of the stress-strain behavior of serpentinite muds from Hole 780D were performed by Phipps and Ballotti (this volume) using a Wykeham Farrance torsion-vane (torvane) apparatus. The results reveal that the serpentinite muds are highly nonideal plastic materials having ultimate strengths ranging from 1.3 to 37.5 kilopascals $(\mathrm{kPa})$, and averaging $11.3 \mathrm{kPa}$ (Fig. 8). For comparison, more "normal" oceanic muds recovered from Site 781 were somewhat stronger, having ultimate strengths that ranged from 8.1 to $116.1 \mathrm{kPa}$ (Phipps and Ballotti, this volume). In only two cases did the samples actually fail. Most serpentinite muds continued to deform at a constant rate at maximum (ultimate) strength. Although no direct determinations of yield strength were made, observations of the behavior of these materials led Phipps and Ballotti (this volume) to suggest that their yield strengths are low to the point of vanishing.

Based on these rheologic measurements, Phipps and Ballotti (this volume) suggest three important conclusions about the mechanics of formation of Conical Seamount: (1) modeling based on the ultimate strengths of the materials suggests that they could transport blocks of serpentinized peridotite (density approximately $2.6-2.7 \mathrm{~g} / \mathrm{cm}^{3}$ ) as 


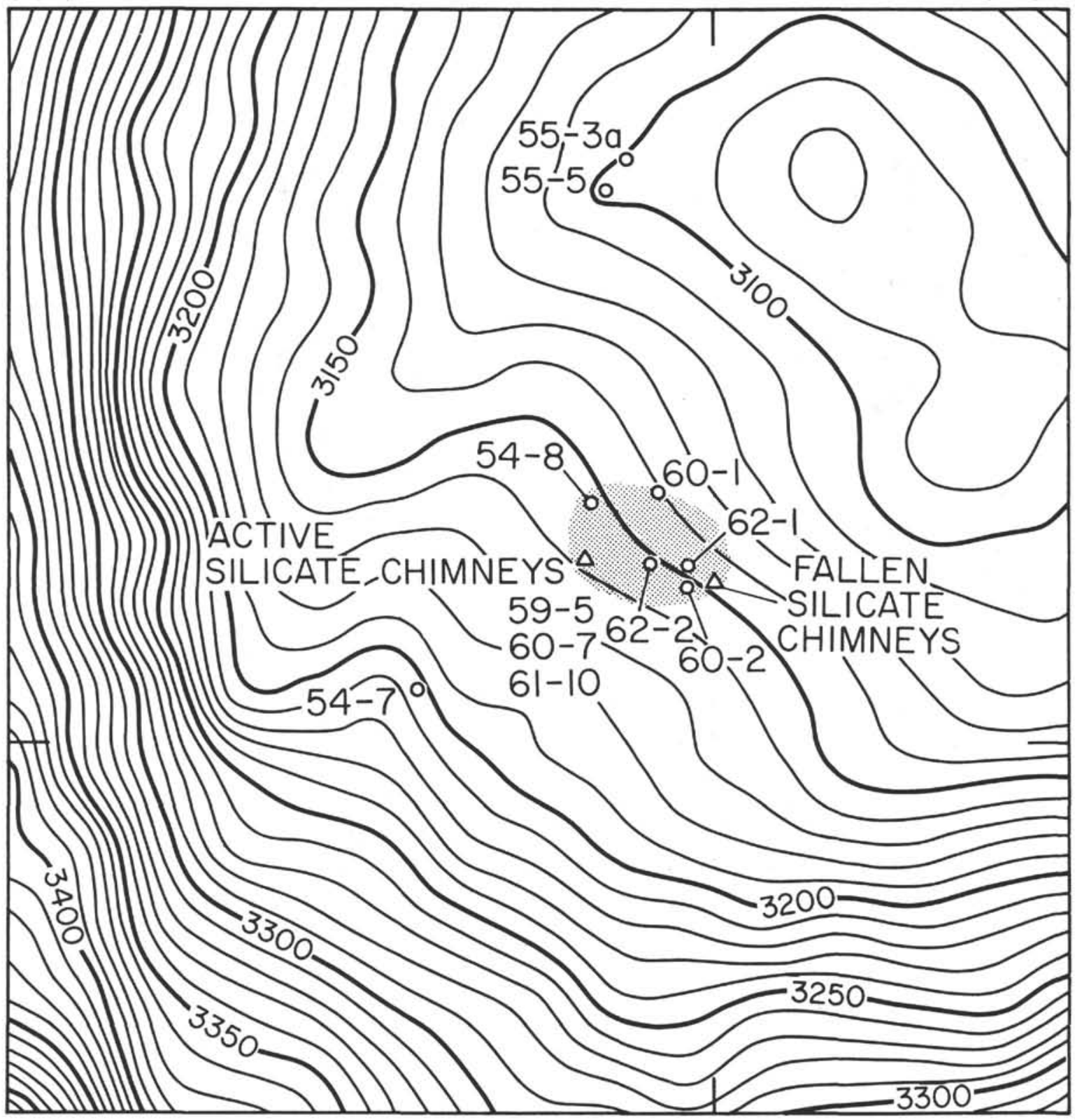

$19^{\circ}$

$\mathrm{N}$

Figure 6. Bathymetry of the summit region of Conical Seamount showing the locations of the four Site 780 holes drilled into the summit (solid circles), the locations of various chimney structures (open circles and triangles), and the vent region (shaded) inferred from the presence of the chimney structures.

large as $20 \mathrm{~m}$ upward against the force of gravity; (2) their low yield strengths suggest that unless the material continues to well upward from within the conduit of the seamount, the blocks will fall back downward into the conduit; (3) their low strengths are consistent with the interpretation that the seamount is rheologically more like a mud volcano than a salt diapir (salt has an ultimate strength of approximately $10^{4}$ to $10^{5} \mathrm{kPa}$ ).

\section{Summit Pore-Water Composition}

The pore fluids from the summit site on Conical Seamount are among the most unusual ever sampled in oceanic sediments (Mottl, this volume). The analyses performed by Mottl (this volume) demonstrate that the fluids have less than one-half the chloride and bromide of seawater. They also have the highest $\mathrm{pH}$ ever measured in samples of pore waters from the deep ocean (maximum value 12.5). High levels of methane, and the presence of ethane, propane, acetate, and organic acids, were measured in the samples (Haggerty and Fisher, this volume; Mottl, this volume). Analyses by Mottl (this volume) show that concentrations of $\mathrm{H}_{2} \mathrm{~S}$ in these samples reach 2 $\mathrm{mmol} / \mathrm{kg}$ and of ammonia reach $270 \mu \mathrm{mol} / \mathrm{kg}$. The pore fluids are enriched relative to seawater in alkalinity $(\times 26)$, sulfate $(\times 1.7), \mathrm{K}$ $(\times 1.5), \mathrm{Rb}(\times 5.6)$, and $\mathrm{B}(\times 10)$. They are highly depleted in $\mathrm{Li}, \mathrm{Mg}$, $\mathrm{Ca}, \mathrm{Sr}$, and ${ }^{34} \mathrm{~S}$, and less so in $\mathrm{Si}, \mathrm{Ba}$, and $\mathrm{Mn}$. They are depleted in $\mathrm{Na}$, but the $\mathrm{Na} / \mathrm{Cl}$ ratio increases to nearly twice the seawater value. These compositions are detected in the upper few meters of the 
A

Lithostratigraphy of Hole 778A

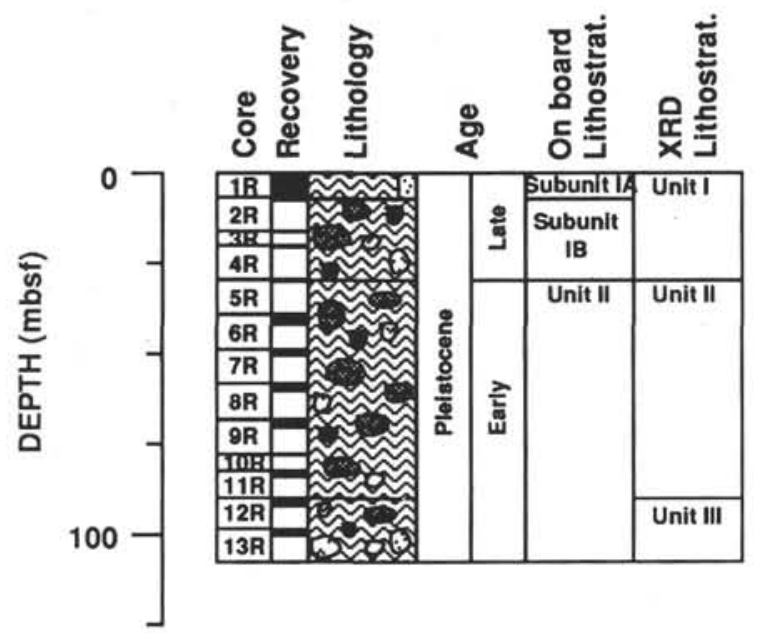

Lithostratigraphy of Hole $780 \mathrm{C}$

C

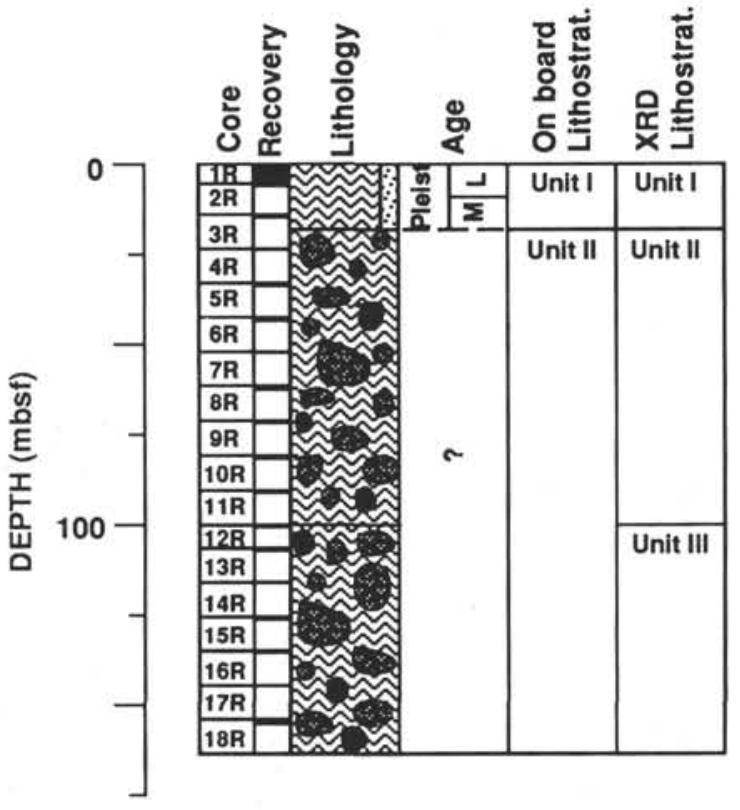

\section{Lithostratigraphy of Hole 779A}

B
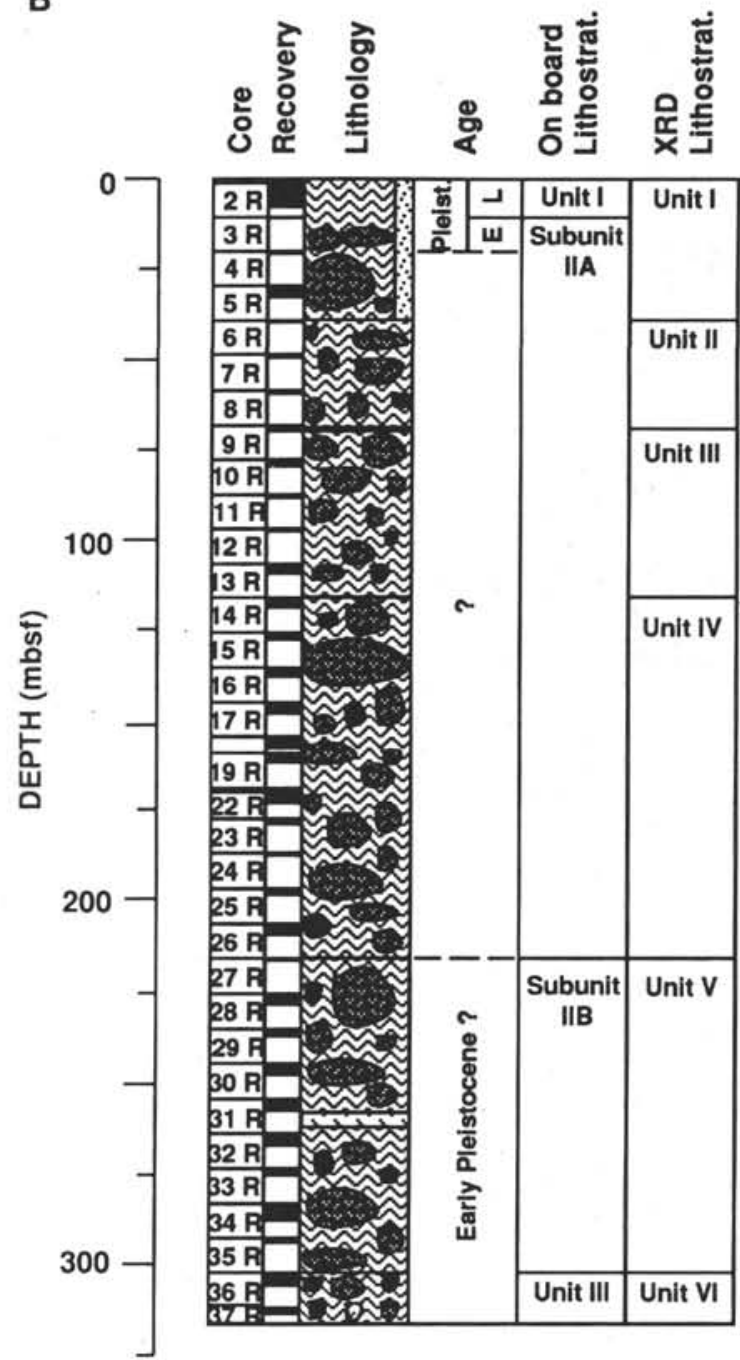

Legend

Clay- and Silt-sized Serpentine, Vitric Siltstone

Clay- and Silt-sized Serpentine with Clasts of Rock

- Serpentinized Harzburgite

- Serpentinized Dunite

08 Meta-basalt or Metadiabase, Various Compositions

Figure 7. Lithostratigraphic summaries of Conical Seamount Holes 778A (A), 779A (B), and 780C (C).

serpentine muds. The large gradients in these pore fluid compositions in the surficial sediments are probably maintained by upflow with velocities on the order of a few millimeters per year through the central conduit of the seamount (Mottl, this volume). The considerable variation in composition of the pore fluids at a given depth among these four holes (drilled within $150 \mathrm{~m}$ of each other) indicates that the distribution of the flow is patchy. Temperature measurements in the summit holes yielded a value of $13.5^{\circ} \mathrm{C}$ at $58 \mathrm{mbsf}$ in Hole 780D. Extrapolation of discrete measurements of temperature in Hole 780C yield a value of $3.7^{\circ} \mathrm{C}$ at the same depth. This suggests that warmer water from the bottom of the deeper hole, Hole $780 \mathrm{D}$, welled up into the hole after it was drilled (Fryer, Pearce, Stokking, et al., 1990), supporting the interpretation that a summit conduit supplies the unusual fluids. This upflow of fluids is also likely responsible for the persistence of aragonite in the surficial serpentine muds.

Some of the compositional characteristics of the fluids can be explained in terms of seawater interactions with peridotites. As Mottl (this volume) points out, the pore fluids at this site are remarkably depleted in $\mathrm{Cl}$. Reduction of chloride in fluids reacting with peridotite is observed experimentally, the chloride being taken up in formation of various secondary phases (Mottl, this volume). If the $\mathrm{Cl}$ depletion is not a primary characteristic of the pore fluids at the summit site, 
there would have to be a phase present in the serpentine muds that could provide a site for the $\mathrm{Cl}$. The presence of the sjogrenite group mineral, iowaite, in the samples of serpentine muds from the summit holes (Fryer and Mottl, this volume; Heling and Schwarz, this volume; Lagabrielle et al., this volume) was suggested by Heling and Schwarz (this volume) to provide a site for the uptake of $\mathrm{Cl}$ from pore waters in the muds when they contact seawater. The facts that iowaite is present in such small quantities in so few of the samples and that the pore fluid samples have such extremely low chlorinity (Mottl, this volume), support the interpretation that the low chlorinity of the pore fluids is a primary characteristic, not a consequence of formation of iowaite. Furthermore, a comparison between the manner in which charge is balanced in the pore fluids and in fluids resulting from experiments with seawater-rock interactions, during which chloride is taken up by the rock, indicates that seawater interaction in a serpentinization reaction is not the major source of the pore fluids from the summit muds.

Pore fluids having low chlorinity have been recovered from other convergent margins during Deep Sea Drilling Project efforts (Mottl, this volume). The low chlorinity of these fluids has been attributed to decomposition of hydrocarbon gas hydrates, membrane filtration, dewatering of clays and opal, and the possible presence of fossil freshwater aquifers. The decrease in chlorinity of the pore fluids in Hole $780 \mathrm{D}$ is larger than any observed in sediment pore fluids in convergent margins. The arguments proposed by Mottl (this volume) for the source of the pore fluid at the summit site suggest dehydration reactions at depth within the subducted Pacific Plate and transport of the resultant fluids through the forearc wedge to the conduit of Conical Seamount.

The ${ }^{87 / 86} \mathrm{Sr}$ isotopic ratios (Haggerty and Chadhuri, this volume) of interstitial waters from this site average 0.70768 ( \pm 000011$)$. This value is 0.001569 to 0.001531 lower than the range of values for seawater and also indicates a non-seawater source for the pore fluids.

Serpentinization has long been suggested as a potential process for mobilizing precious metals. Analyses of platinum-group elements in the peridotites and associated pore waters, however, indicate that seawater peridotite interactions have not mobilized these elements (Parkinson et al., this volume).

Analyses of the pore waters for organic acids by Haggerty and Fisher (this volume) indicate that an organic component may be present in the fluids or in the solid materials entrained within the rising serpentine. The Leg 125 samples provide the first evidence for short-chain organic acids from interstitial fluids associated with serpentine. Organic acids (dominantly formate) and the alkanes, methane, and ethane are present in pore fluids from serpentine muds of the summit holes. The presence of these species indicates the existence of more complex organic precursors, and of the pore fluid samples analyzed from Leg 125 , only those associated with serpentine muds contain organic acids. The ultimate origin of the precursor material cannot be determined unambiguously from the analytical data. Haggerty and Fisher (this volume) note that this organic matter may derive from several sources. Circulation of overlying seawater into the seamount might provide the precursor material. Haggerty and Fisher (this volume), however, suggest that because the precursor compounds are likely to be of high molecular weight and to be relatively insoluble in seawater they are unlikely to be transported by seawater circulating through the seamount. They also note that the $\mathrm{Sr}$ isotopic composition of the pore fluids would be higher if seawater were the source of the organic compounds. That the highest concentrations of organic acids are found at the summit site and that metasediment clasts and slightly higher organic carbon contents also occur in the summit samples has prompted Haggerty and Fisher (this volume) to suggest that the production of the organic acids results from organic precursors entrained within the rising serpentine muds. They note, however, that their data are also consistent with both the precursor compounds being derived from the downgoing slab and with production of organic acids through alkaline hydrolysis of ester

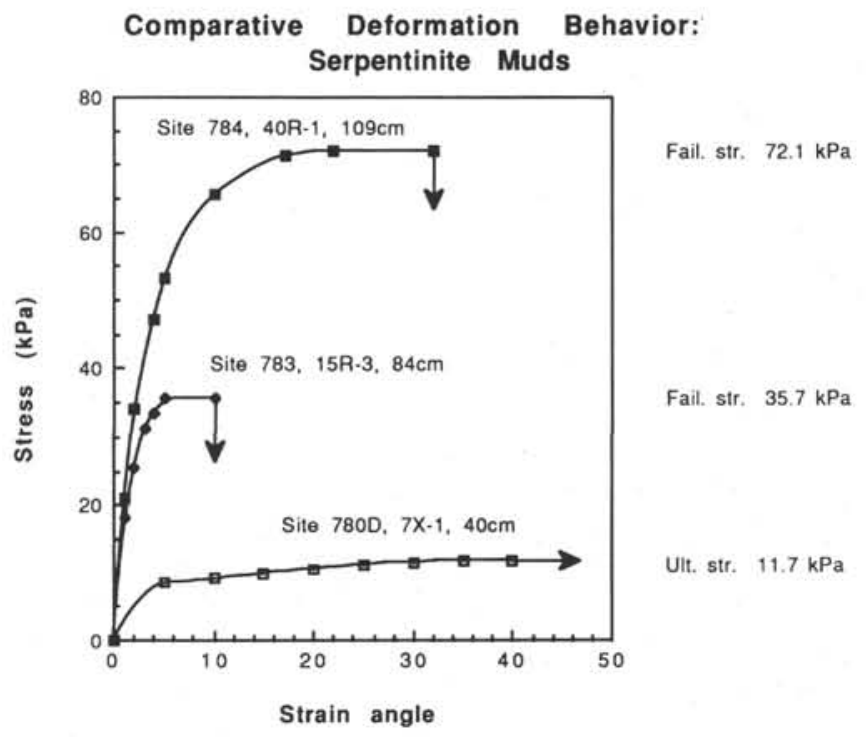

Figure 8. Comparative deformation behavior of serpentine muds from Leg 125 holes on Conical Seamount (Site 780) and Torishima Forearc Seamount (Sites 783 and 784) (from Phipps and Ballotti, this volume).

linkages within the serpentine muds. They conclude that organic acids may have a thermal origin from organic precursors in the downgoing slab or entrained within the serpentine muds, but may also be produced chemically in the rising fluids within serpentine muds of Conical Seamount.

\section{Conical Seamount Flank (Sites 778 and 779)}

Two sites were drilled on the flanks of Conical Seamount, Sites 778 and 779 (Fig. 2). The stratigraphic section recovered at Site 778, on the south flank, is divided into two lithologic units, based on shipboard observations (Figs. 7B, 7C). Lithologic Unit $\mathrm{I}$ is distinct in that it alone contains sediment with detrital and biogenic components. Unit I consists of Subunit IA from 0.0 to $7.2 \mathrm{mbsf}$, in Sections 125-778A-1R-1, $0 \mathrm{~cm}$, to $125-778 \mathrm{~A}-2 \mathrm{R}-1,50 \mathrm{~cm}$, Holocene (?) to upper Pleistocene. This subunit is composed of clay, marl, clay-sized serpentine, serpentine breccia, and pebbles of various lithologies. Shipboard examination of smear slides from this subunit indicates serpentine $(65 \%)$, opaques $(10 \%)$, epidote/zoisite $(10 \%)$, aragonite $(10 \%)$, nannofossils $(5 \%)$, and trace amounts of radiolarians and silicoflagellates comprise the subunit. Abundant aragonite in these serpentine flows is unusual in waters this deep on the forearc (Haggerty, 1987b). The delicate, acicular aragonite crystals in the clay and serpentine imply in-situ, authigenic growth after the serpentine was emplaced (Fryer and Mottl, this volume).

Subunit IB, from 7.2 to $29.8 \mathrm{mbsf}$, in Sections 125-778A-2R-1, $50 \mathrm{~cm}$, to $125-778 \mathrm{~A}-5 \mathrm{R}-1,10 \mathrm{~cm}$, is defined on the basis of an interval of cobbles and pebbles, possibly representing drilling breccia. Two of the pebbles contain biogenic components and yielded ages of upper Pleistocene to lower Pleistocene(?). In one were trace amounts of poorly preserved radiolarians and Neogene planktonic foraminifers in a clay matrix; coarser grains include rock fragments of vesicular volcanics and crystals of olivine. The lowest pebble in this section is a foraminifer-bearing serpentine sandstone of Pleistocene age composed of serpentine $(65 \%)$, opaques $(12 \%)$, epidote $(10 \%)$, chlorite $(5 \%)$, aragonite $(5 \%)$, foraminifers $(3 \%)$, and a trace amount of nannofossils.

Lithologic Unit II from 29.8 to 107.6 mbsf, in Sections 125-778A$5 \mathrm{R}-1,10 \mathrm{~cm}$, to $125-778 \mathrm{~A}-13 \mathrm{R}-\mathrm{CC}$ is composed of serpentinite breccia having phacoidal and sheared textures and some convolute structures. Convolute structures appear in several sections. The origin 
of these structures is controversial. They are reminiscent of deformation structures produced by purely tectonic or purely gravitational flow processes, but may have resulted, at least in part, from drilling disturbance. Intervals of serpentinized ultramafic cobbles and pebbles are also present in Lithologic Unit II. The unit had poor recovery. The occurrence of pebbles, lacking an associated matrix, at tops and bases of longer cores (midsections contain sediment or serpentine), or as the only material recovered in shorter cores, argues for removal of fine-grained material by washing during coring. The matrix of the breccia in this unit is similar to that of Subunit IA. It is composed of serpentine $(50 \%-80 \%)$, opaques $(5 \%-20 \%)$, thulite(?) $(0 \%-25 \%)$, epidote/zoisite $(0 \%-30 \%)$, chlorite $(0 \%-15 \%)$, talc $(5 \%-0 \%)$, olivine (5\%-0\%), and albite ( $0 \%$ to trace).

Results of shore-based X-ray diffraction (XRD) analysis of serpentine matrix and clast samples also indicate that drilling at Site 778 on the south flank penetrated at least three units of serpentine mud flows (Fryer and Mottl, this volume; Heling and Schwarz, this volume; Lagabrielle et al., this volume). The units are based on mineralogical and compositional differences and do not correspond stratigraphically with lithologic units denoted by shipboard observations. The first of these units, from 0 to $30 \mathrm{mbsf}$, includes all of shipboard Lithologic Unit I and the upper approximately $20 \mathrm{~m}$ of Lithologic Subunit IIA. The upper unit contains serpentine (dominantly chrysotile), aragonite, sjogrenite group minerals, Feoxides, and halite (Fryer and Mottl, this volume; Heling and Schwarz, this volume; Lagabrielle et al., this volume). Heling and Schwarz (this volume) have also identified garnierite, a poorly crystallized $\mathrm{Ni}$ chrysotile, in the samples. Bulk compositions of the samples show variable $\mathrm{SiO}_{2}, \mathrm{MgO}$ contents, but a $\mathrm{SiO}_{2} / \mathrm{MgO}$ ratio close to 1 (Heling and Schwarz, this volume; Lagabrielle et al., this volume). The samples are enriched in $\mathrm{CaO}$, reflecting the presence of the carbonate. The samples have low $\mathrm{Al}_{2} \mathrm{O}_{3}$ and high concentrations of $\mathrm{K}_{2} \mathrm{O}, \mathrm{Na}_{2} \mathrm{O}$, and $\mathrm{Sr}$. The second of the units based on XRD and geochemical analysis is from 30 to 90 mbsf, according to Fryer and Mottl (this volume), and from 30 to about $77 \mathrm{mbsf}$, according to Lagabrielle et al. (this volume). This represents most of Lithologic Unit II. This second compositional unit is characterized by serpentine, sjogrenite group minerals, and authigenic garnet. Carbonate is present as calcite not aragonite. Chlorite is also present. The bulk composition of the serpentine muds is similar to that of the rock clasts entrained within this unit (Lagabrielle et al., this volume). The third compositional unit is represented by samples from depths greater than $90 \mathrm{mbsf}$, according to Fryer and Mottl (this volume), and from depths greater than 77 mbsf, according to Lagabrielle et al. (this volume). The discrepancy in the unit boundaries of these workers may be the result of sample selection. Further detailed work will be required to remove the discrepancy. Serpentine is less abundant relative to the other mineral phases in the third unit. Sepiolite, palygorskite, chlorite-smectite, and accessory amphiboles, pyroxenes, and hematite are present in the muds (Fryer and Mottl, this volume; Lagabrielle et al., this volume). Studies of the bulk composition of the muds from this deepest compositional unit indicate geochemical characteristics related to the presence of mafic components (isolated minerals or lithic fragments) within the serpentine muds (Lagabrielle et al., this volume). The deepest compositional unit also contains the greatest diversity of clast types in Hole 778A. The studies of Lagabrielle et al. (this volume) show that the polymict nature of the unit extends locally to a much finer scale. The lower compositional unit may indicate a period during which the serpentinite experienced reworking brecciation and resedimentation (possibly coeval) with derivation of mafic components from nearby scarps or from volcanics emplaced within the serpentine (Lagabrielle et al., this volume). The serpentinite of the lower unit thus may be derived as debris flows of serpentine from exposed fault scarps of ultramafics as opposed to mud flows of serpentine from a central conduit as is hypothesized for the upper two units. The upper two units derive from a source having relatively little change in composition. Furthermore, the mineralogy and structures of the upper two units indicate flow emplacement.

The stratigraphic section recovered at Hole $779 \mathrm{~A}$, on the southeast flank of the seamount, is divided into three lithologic units, based on shipboard observations. Lithologic Unit I, from 0 to $10.6 \mathrm{mbsf}$, in Sections 125-779A-1R-1, $0 \mathrm{~cm}$, to $125-779 \mathrm{~A}-2 \mathrm{R}-5,68 \mathrm{~cm}$, consists of clay, clay-sized serpentine, and serpentine having clasts of serpentinized ultramafics. Composition ranges from serpentine $(60 \%-$ $75 \%)$, opaques $(7 \%-20 \%)$, aragonite $(0 \%-15 \%)$, epidote/zoisite $(5 \%-10 \%)$, clay $(0 \%-5 \%)$, chlorite $(0 \%$ to a trace), and garnet $(0 \%$ to a trace). Only Unit I contains sediment with well-preserved microfossils that indicate an early Pleistocene age, a maximum age for deposition of the serpentine. Brown serpentine mud in the first core contains clay $(40 \%)$, serpentine $(32 \%)$, chlorite $(5 \%)$, opaques $(3 \%)$, foraminifers $(10 \%)$, nannofossils $(5 \%)$, radiolarians $(5 \%)$, and trace amounts of lithic fragments, diatoms, and sponge spicules.

Unit II, from 10.6 to $303.0 \mathrm{mbsf}$, in Sections 125-779A-3R-CC to 125-779A-35R-1, $133 \mathrm{~cm}$, yields an age of lower Pleistocene (?) to lower Pliocene (?). It contains clasts of various igneous and metamorphic lithologies in a serpentine matrix. This matrix is composed of silty clay-sized serpentine $(73 \%-90 \%)$, amphibole (?) $(5 \%-10 \%)$, opaques $(5 \%-10 \%)$, thulite (?) $(0 \%-25 \%)$, epidote/zoisite $(0 \%-$ $15 \%)$, chlorite $(0 \%-5 \%)$, with trace amounts of garnet, plagioclase (?), and olivine. The unit is divided into two subunits because sedimentary strata with primary sedimentary structures are intercalated in the lower portion of the unit.

Subunit IIA, from 10.6 to 216.2 mbsf, in Sections 125-779A-3R$\mathrm{CC}$ to $125-779 \mathrm{~A}-26 \mathrm{R}-3,150 \mathrm{~cm}$, yields an age of lower Pleistocene(?). This subunit is composed of blocks of serpentinized harzburgite and dunite, metabasalt, and serpentinite in a serpentine matrix. The matrix of this subunit is usually highly deformed by drilling, although in some cases primary structural features can be observed. The matrix shows both a simple, sheared and a phacoidal, sheared texture. The sedimentary strata in Subunit IIA contain carbonate grains, kerogen, and filamentous opaque debris interpreted as remnants of bacteria in smear slides (Cores 125-779A-27R, -28R, and $-32 R)$. The kerogen indicates a primary sedimentary origin rather than a tectonic or igneous origin.

Lithologic Subunit IIB differs from Lithologic Subunit IIA in that it has sediment intervals with distinct primary sedimentary and biologic structures. Subunit IIB, from 216.2 to $303.0 \mathrm{mbsf}$, in Sections $125-779 \mathrm{~A}-27 \mathrm{R}-1,0 \mathrm{~cm}$, to $125-779 \mathrm{~A}-35 \mathrm{R}-1,133 \mathrm{~cm}$, yields an age of lower Pliocene(?). Faint horizontal bedding and sedimentary structures were observed in the sediments of Subunit IIB, suggesting a primary sedimentary origin. Clay layers with filamentous organics are horizontal and separate layers above and below that have deformational structures. These clay layers may represent periods of exposure on the seafloor or hiatuses between episodes of serpentine flow deposition. A mafic layer (a large diabase clast or a sill/flow unit) is present at about 295 mbsf in Core 125-779A-31R. Sparse nannofossils of late Miocene/early Pliocene age, with reworked Oligocene nannofossils, have been identified in Sample 125-779A-27R, $60 \mathrm{~cm}$. No additional microfossils were found in Unit II. Therefore, the base of Unit II is interpreted as having been deposited during or prior to the early Pliocene. An early Pleistocene age determined from sediments in the core catcher of Core 125-779A-2R limits the youngest time of deposition of Unit II.

Lithologic Unit III, 303.0 to 317.2 mbsf, in Sections 125-779A$36 \mathrm{R}-1,0 \mathrm{~cm}$, to $125-779 \mathrm{~A}-37 \mathrm{R}-\mathrm{CC}$, is composed of serpentinite microbreccia that has convolute structures. The matrix of the breccia is composed of serpentine $(70 \%-90 \%)$, opaques $(4 \%-10 \%)$, chlorite $(0 \%-20 \%)$, epidote/zoisite $(0 \%-14 \%)$, amphibole $(0 \%-5 \%)$, micrite (trace to $5 \%$ ), and trace amounts of garnet, dolomite, and organic debris. These convolute structures possibly result from a combination 
of drilling disturbance and primary deformational textures produced by tectonic or gravitational flow processes.

Hole $779 \mathrm{~B}$ is $100 \mathrm{~m}$ east of Hole $779 \mathrm{~A}$. The detrital material in the only core recovered from Hole 779B is a dark-brown, serpentine silt and silty sand having trace amounts of radiolarians, silicoflagellates, nannofossils, and foraminifers. Yellow to brownish yellow, silt-sized serpentine is interlayered with the dark-brown serpentine silt in the first cores from both Holes 779A and 779B. The yellow silt is stiff, very deformed, and lacks biogenic components. This silt-sized serpentine from both cores typically contains authigenic aragonite needles. On the basis of similar lithologies and biostratigraphic criteria, Lithologic Unit I from Site 779 correlates with Unit I at Site 778.

Shore-based analyses of samples of the serpentine muds from Hole 779A by XRD indicate only subtle changes in mineralogy with depth in the hole (Fryer and Mottl, this volume). The mineralogical changes, in addition to the shipboard observations of differences in lithology and structures of the cores, suggest six possible flow units. The mineralogical data indicate a unit from 0 to 39 mbsf composed of serpentine, chlorite, clays, with minor carbonate (aragonite only in the upper portion), sjogrenite group minerals, and rare goethite and loughlinite. An increase in diversity of the mineralogy of the cores from 39 to 69 mbsf indicates a second unit. The third unit, from 69 to $116 \mathrm{mbsf}$, is marked by a decrease in diversity of mineralogy in the cores. Between 116 to 216 mbsf, the muds contain lizardite and possibly antigorite and are suggested by Fryer and Mottl (this volume) to constitute a fourth unit. Between about 216 to $303 \mathrm{mbsf}$, the serpentine muds contain biogenic material in various forms and constitute a fifth unit. Kerogen was described from several cores in this interval, and nannofossils were identified in smear slides (Fryer, Pearce, Stokking, et al., 1990). Apparent pelagic sediment layers are intercalated with the serpentine muds in this interval, suggesting long periods of exposure on the seafloor. A mafic unit (possibly a large clast or a sill/flow) is present in this unit. This fifth unit was suggested by Fryer and Mottl (this volume) to represent a sequence of flows or debris units having a slower rate of extrusion or having been exposed on the seafloor for considerable periods. The sixth unit is described by Fryer and Mottl as containing a greater diversity of minerals than in any of the shallower units. Greenalite, the rare, iron-rich serpentine phase, is probably present in this unit. Amphibole, not observed in any of the shallower units, is also present in this interval. Extant orthopyroxene grains are present in the muds. Fryer and Mottl (this volume) suggest that these six units constitute a series of flows or debris units that include influx from several sources.

The general lithologic pattern in the two flank sites suggests that a direct correlation among the various flow units is speculative at best. Possibly the 0 to $30 \mathrm{mbsf}$ unit of Hole 778A represents a recent pulse of activity on the seamount and the 30 to 90 mbsf unit at Hole $778 \mathrm{~A}$ might be correlated lithologically with the units from 0 to $39 \mathrm{mbsf}$ of Hole $779 \mathrm{~A}$. The units containing the more diverse mineralogy ( 90 to $108+$ mbsf of Hole $778 \mathrm{~A}$ and 39 to 216 mbsf of Hole 779A) also may correspond. To determine the details of possible correlations between the units at these sites and to define precisely the variations in mineralogy of the muds in these intervals a more thorough study will be required.

\section{Flank Structures}

At Site 778 , the foliated and clastic serpentinites recovered are highly disturbed, especially in Unit II, where the layers are affected by intense plastic deformation (folding) and ductile shearing. This deformation seems to have occurred in the presence of high fluid contents.

Possible mechanisms responsible for the observed structures are (1) drilling disturbances; (2) syn-emplacement slumps (i.e., deformation during pure gravitational flow); (3) ball-and-pillow structures (density differences in liquefied sediments); (4) dewatering of soft sediments (water escape structures); (5) fluid-circulation disturbances ("upwelling" of hydrothermal fluids of deep origin); and (6) pure tectonic processes within the diapir. Some of these mechanisms may have acted together.

Small-scale original layering within Unit II is apparently preserved locally, most often defined by alternating zones of gravelly serpentine muds of different colors within abundant irregular folds. Foliation, either horizontal or oblique, is present especially around major shear bands in the cores. The foliation is emphasized both by alignment of stretched millimeter- to centimeter-sized clasts of serpentine and by discontinuous, sheared laminae. A thin, anastomosing cleavage, similar to scaley-clay cleavages (argille scagliose) has also developed, almost parallel to the foliation. This cleavage is locally emphasized by the development of pale green laminae (chrysotilerich laminae?). A preliminary shipboard study of the microfabric of the matrix, using impregnated thin sections, suggests that the foliation is well-defined locally by the preferred orientation of the serpentine flakes. This preferred orientation is notably visible under crossed nicols, where contiguous portions of the thin sections tend to go to extinction simultaneously. However, on this scale, the deformation is not homogeneous and it is not possible to define a uniform field of deformation. On these grounds, it would appear that the deformation intensity has not been large enough to provide a significant rearrangement of the material. Garnet (identified on board the ship as hydrogrossular) crystals locally form long chainlets and clusters that are clearly located within the foliation planes. Epidote-group minerals (mainly? zoisite) have been found. These minerals are located within the foliation planes indicating that crystallization is pre-deformation to syn-deformation.

Decimeter-size folds affect the foliation. This observation is confirmed by thin-section analysis that shows tightly folded and sheared serpentine monocrystals. Anastomosing foliation planes and curving foliation planes around clasts define shear lenses (phacoids) on all scales. Lenses are of millimeter to centimeter scale. At this scale, however, the weakly preferred orientation of the shear planes and lenses does not permit precise definition of the senses of shear. Decimeter-sized shear bands can be recognized locally throughout Cores $125-778 \mathrm{~A}-5 \mathrm{R}$ to $-13 \mathrm{R}$. Oblique bands are particularly visible in Section 125-778A-7R-1 at 85 and $120 \mathrm{~cm}$. Small centimeter-tomillimeter shear bands are abundant within all the sections. The presence of horizontal to gently dipping shear zones suggests that horizontal displacement took place on the flank of the seamount. Such displacements probably result from gravitational instability of the upper part of the seamount.

Deformation patterns in Lithologic Unit III of Site 779 are similar to those described in Lithologic Unit II of Hole 778A. Deformation within the sediments of Lithologic Unit III also is consistent with gentle flow under gravitational forces. The layered-serpentinite microbreccias also frequently show a succession of plastic folds, termed "convolute folding." These folds are oblique to the core axis and are helicoidal. They are thought to have resulted from drilling disturbance.

\section{Flank Pore-Water Composition}

A comparison of the pore fluids of the summit Site 780 with those of the flank Sites 778 and 779 shows an admixture of a deep source component, possibly from the subducted slab, that has a component derived through the interaction of seawater with peridotite (Mottl, this volume). The reaction of seawater with peridotite produces a fluid that is low in methane; lacks ethane and propane; has low carbonate alkalinity, sulfate, $\mathrm{B}$, and $\mathrm{K}$; has slightly lower $\mathrm{Li}$ and $\mathrm{Rb}$; is little changed with respect to chlorinity, $\mathrm{Be}, \mathrm{Na}$, and $\mathrm{Na} / \mathrm{Cl}$; and has high $\mathrm{Ca}, \mathrm{Sr}, \mathrm{Ba}$, and ${ }^{34} \mathrm{~S} /{ }^{32} \mathrm{~S}$ (Haggerty and Chadhuri, this volume; Mottl, this volume; Mottl and Alt, this volume). Such a fluid would also have high $\mathrm{pH}$ and ammonia and low $\mathrm{Mg}, \mathrm{Si}$, and $\mathrm{Mn}$. Mottl (this volume) suggests that to a first approximation, the Conical Seamount flank 
Sites 778 and 779 are mixtures of the slab component and the component derived from seawater interaction with peridotite. The pore fluids from Site 779 are richer in the slab component.

Haggerty and Chadhuri (this volume) find that the ${ }^{87 / 86} \mathrm{Sr}$ isotopic ratios of interstitial waters from this site average 0.70650 $( \pm 0.000009)$. They note that these values are 0.00274 to 0.002711 lower than the range of values for seawater, indicating multiple sources for the interstitial waters. These sources include seawater and an igneous source, possibly derived from dehydration of the subducting Pacific Plate (Haggerty and Chadhuri, this volume), and support the conclusions of Mottl (this volume).

\section{Conical Seamount Petrology}

Conical Seamount bears a range of rocks from ultramafic to several mafic types. The composition of the ultramafic samples is dominantly harzburgite and minor dunite (Ishii et al., this volume; Saboda et al., this volume). Microstructures in the peridotites from Conical Seamount indicate a multistage history of formation of the peridotites (Girardeau and Lagabrielle, this volume). Enrichment in light rare-earth elements suggests that a sub-solidus enrichment after melting has occurred (Parkinson et al., this volume). This pattern of enrichment is similar to that observed in ophiolites generated above subduction zones (Parkinson et al., this volume). However, such supra-subduction zone ophiolites do not show the extreme pattern characteristic of the samples analyzed from the Mariana and IzuBonin sites of Leg 125 (Parkinson et al., this volume). The pattern of enrichment of the Leg 125 peridotites may reflect the influence of slab-derived fluids in the serpentinization process. Platinum-group elements and $\mathrm{Au}$ phases are absent from the serpentine samples (Parkinson et al., this volume). The opaque phase present in the rocks is principally magnetite that formed during serpentinization of the peridotites (Stokking et al., this volume). Stokking et al. (this volume) demonstrate that formation of secondary magnetite, although complex, increases with degree of serpentinization, as grain size of the magnetite increases. Their data indicate that the serpentine muds show no systematic differences from the entrained peridotites in magnetic behavior. This factor indicates either derivation of the serpentine mud from the same source material as that which supplies the clasts, or alteration in the muds of the magnetite from the source peridotite to a mineral having similar magnetic characteristics and abundance as magnetite (such as maghemite) (Stokking et al., this volume). Stokking et al. (this volume) note that the volume susceptibilities of serpentinized peridotites are less than those obtained from other submarine rocks. They emphasize, however, that because the seamounts are large edifices, their contribution to forearc magnetization must not be neglected when developing models of magnetic anomalies in forearc regions (Stokking et al., this volume).

Studies of the seismic properties of the peridotite samples from Conical Seamount (Ballotti et al., this volume) have emphasized the newly discovered importance of the effect of porosity on the physical properties of oceanic serpentinite to depths of approximately $7 \mathrm{~km}$ below the seafloor. The compressional velocities measured in samples of serpentinized peridotite with densities greater than $2.55 \mathrm{~g} / \mathrm{cm}^{3}$ are within the range of values for previously studied samples of comparable mineralogy and composition. However, those samples having a density of less than $2.55 \mathrm{~g} / \mathrm{cm}^{3}$ are anomalous. Such unusually low densities have not been measured previously in serpentinized peridotites. Ballotti et al. (this volume) demonstrate that the low densities in these peridotite samples are related to high porosities, not merely to the hydration of olivine, the commonly attributed cause of density reduction in serpentinized peridotites. The trend in Poisson's ratio of the Leg 125 samples is inversely proportional to porosity. Studies of oceanic basalts by Hyndman and Drury (1976) indicated that high porosity decreases Poisson's ratio. The Leg 125 serpentine supports this conclusion, although Ballotti et al. (this volume) caution that porosity may affect Poisson's ratios of basalts differently from serpentinites. The unusual porosity of the Leg 125 serpentinite samples may be related to the presence of a locally high fluid flux during serpentinization.

Mafic clasts recovered in the serpentine muds of Conical Seamount are less than $9 \%$ by volume of the total rock recovered (Johnson, this volume; Maekawa et al., this volume). These mafic clasts are dominantly metabasalt or metadiabase, but also include boninite and cumulate gabbro. Based on trace element concentrations, the mafic rocks comprise five geochemical groups, island-arc tholeiite, boninite, mid-ocean-ridge basalt, basalt intermediate between island arc tholeiite and mid-ocean-ridge basalt, and ocean-island basalt (Johnson, this volume). The presence of clasts of basalts having mid-ocean-ridge, trace element signatures in the serpentine muds and evidence from dredged rocks, described above, suggest that either a large region of the forearc may be underlain by or interspersed with fragments of accreted oceanic plate, or that forearc volcanism producing MORB-like lavas took place in the vicinity of Conical Seamount (Fig. 9). Metamorphism of the mafic samples took place principally under low-temperature and low-pressure conditions (Maekawa et al., this volume). Some of the mafic rocks from Site 778 contain blueschist-facies metamorphic minerals and are considered to have been derived from a deep $(12-18 \mathrm{~km})$ portion of the forearc (Maekawa et al., this volume).

The composition of the mafic clasts from Sites 778 and 779 overlap. However, there is a difference in the mode of occurrence of the mafic clasts in the two sites (Johnson, this volume). Mafic clasts are scattered relatively evenly throughout Hole 778A. Six of the thirteen cores from Hole $778 \mathrm{~A}$ contain isolated, rounded fragments of brecciated metabasalt, generally 2 to $8 \mathrm{~cm}$ in diameter and ordinarily present in direct contact with serpentine muds ( $9 \%$ of the total recovery). In Hole $778 \mathrm{~A}$, clasts that are diverse in composition lie adjacent to each other and are therefore not considered to be part of a continuous block (Johnson, this volume). Although the clasts from Hole $779 \mathrm{~A}$ are similar with respect to the total recovery $(7 \%)$ to those from Hole 778A, those from Hole 779A are restricted stratigraphically. They occur in only three intervals within the 37 cores recovered. In only one of these intervals is the mafic clast (Core 125-779A-36R, sample 1) a small isolated fragment within a serpentine mud matrix, as are those throughout Hole 778A. The other two occurrences constitute a $62 \mathrm{~cm}$ and a $390 \mathrm{~cm}$ interval. Johnson (this volume) suggested that the difference in the mode of occurrence of the mafic clasts in the two holes may be related to the source area of the serpentine flows or to the internal structure of the seamount.

The mode of occurrence and the distribution of all clasts (including ultramafic clasts) in general varies in a similar manner. In Hole $778 \mathrm{~A}$ the clasts constitute about $39 \%$ of the total material recovered and generally occur as subangular to subrounded clasts with maximum length averaging $6.5 \mathrm{~cm}$. No clast is greater than $17 \mathrm{~cm}$ long. In Hole $779 \mathrm{~A}$ the clasts constitute $66 \%$ of the total recovery. Although there are small, subangular to subrounded clasts in the cores from Hole $779 \mathrm{~A}$, the average maximum size for the clasts is $32 \mathrm{~cm}$ and most of the cores contain intervals of ultramafic rock that are from 20 to 63 $\mathrm{cm}$ long. In the summit Hole $780 \mathrm{C}$ (the deepest of the summit holes) the clasts comprise $64 \%$ of the total recovery and have an average maximum size of about $12 \mathrm{~cm}$. Most are subangular to subrounded blocks from about 3 to about $15 \mathrm{~cm}$ long. One large clast is $115 \mathrm{~cm}$ long.

Any discussion of the possible causes for the clast distribution observed must first point out that the total recovery in the deep Conical Seamount holes is low; $21.2 \%$ for Hole 778 A; $22.9 \%$ for Hole $779 \mathrm{~A}$; and $8.8 \%$ for Hole $780 \mathrm{C}$. The low recovery probably results from washing away during drilling of much of the unlithified serpentine mud that forms the matrix of the serpentine flows. The clasts are probably over-represented among materials recovered in drilling. The rate of recovery in the two flank holes, 778 A and 779A is nearly identical. Therefore, it is likely that clast populations in these holes 
A

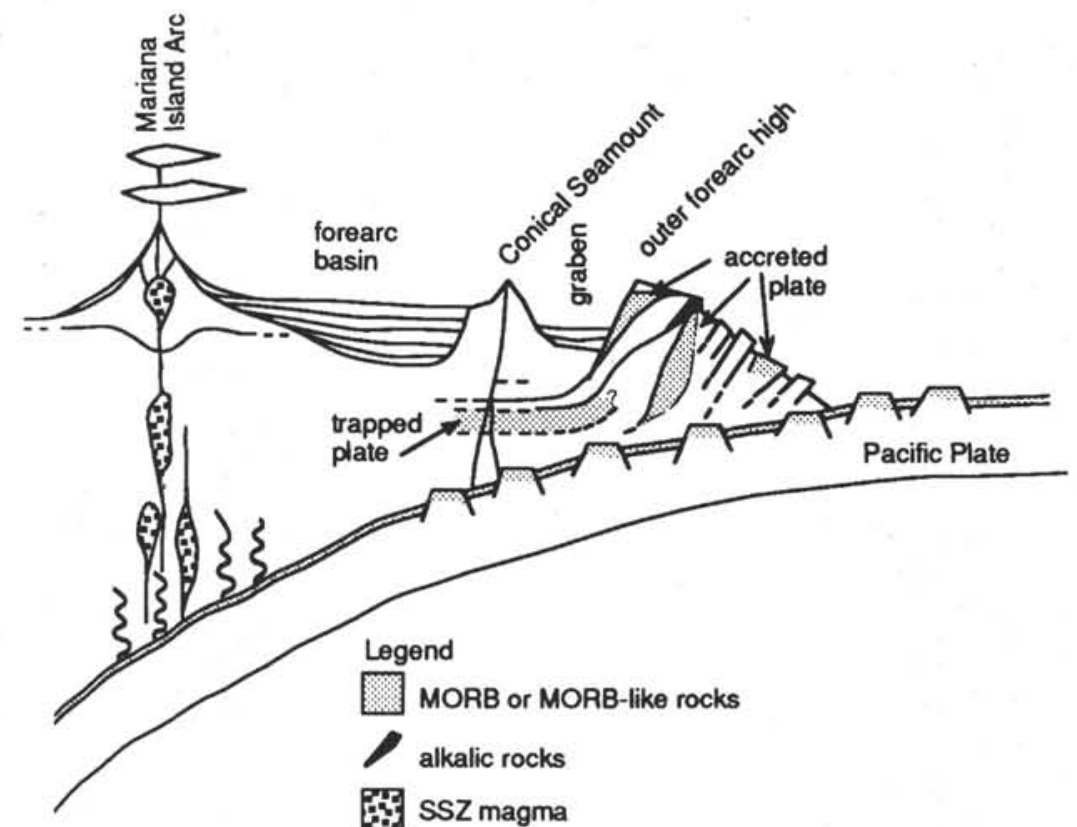

B

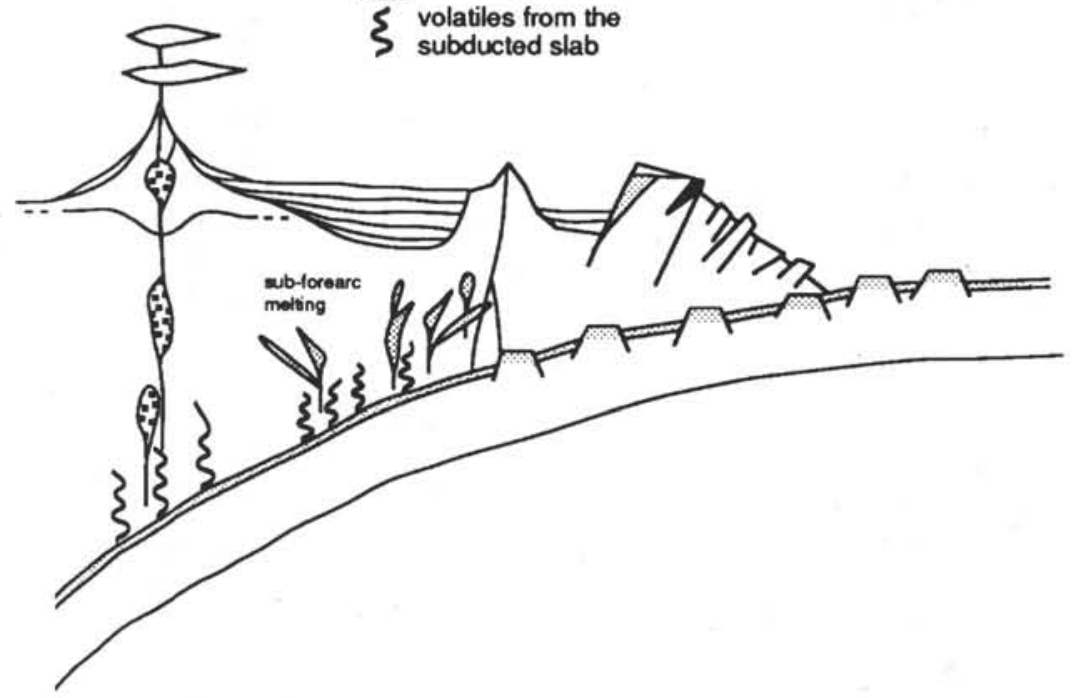

C

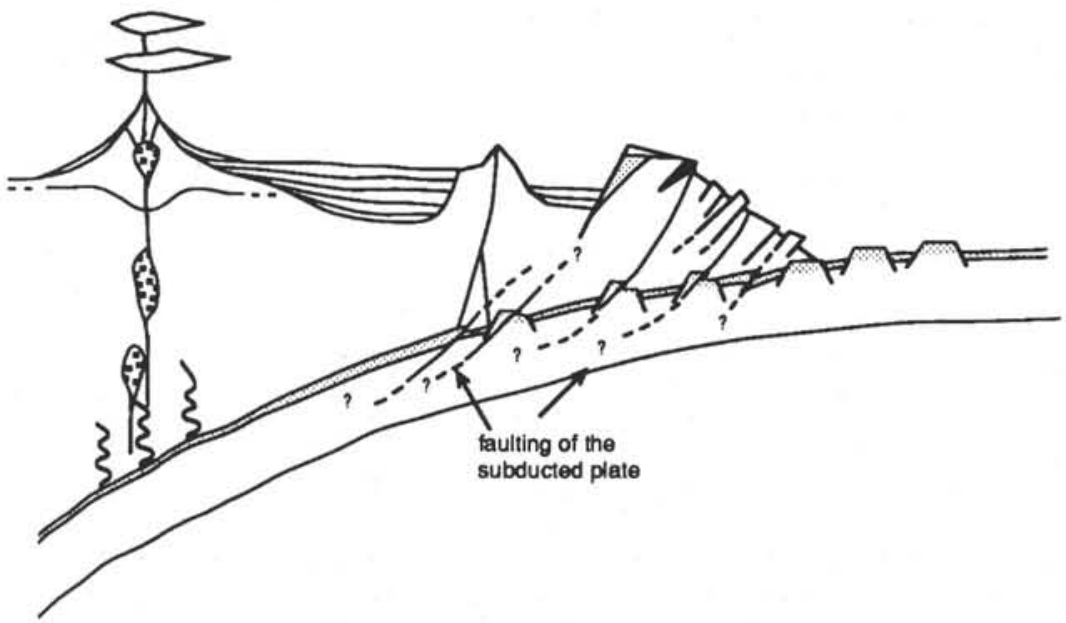

Figure 9. Schematic cross sections through the Mariana arc and forearc regions at the latitude of Conical Seamount, depicting three possible sources for the mafic clasts recovered from Holes 778A and 779A in Conical Seamount. A. Derivation of the MORB-like lavas from a fragment of trapped plate. B. Derivation of the MORB-like lavas from deep forearc magmatic sources. C. Derivation of the MORB-like lavas from fragmented portions of subducted plate within the source region of the serpentine muds (from Johnson, this volume). 


\section{A Lithostratigraphy of Hole 783A}

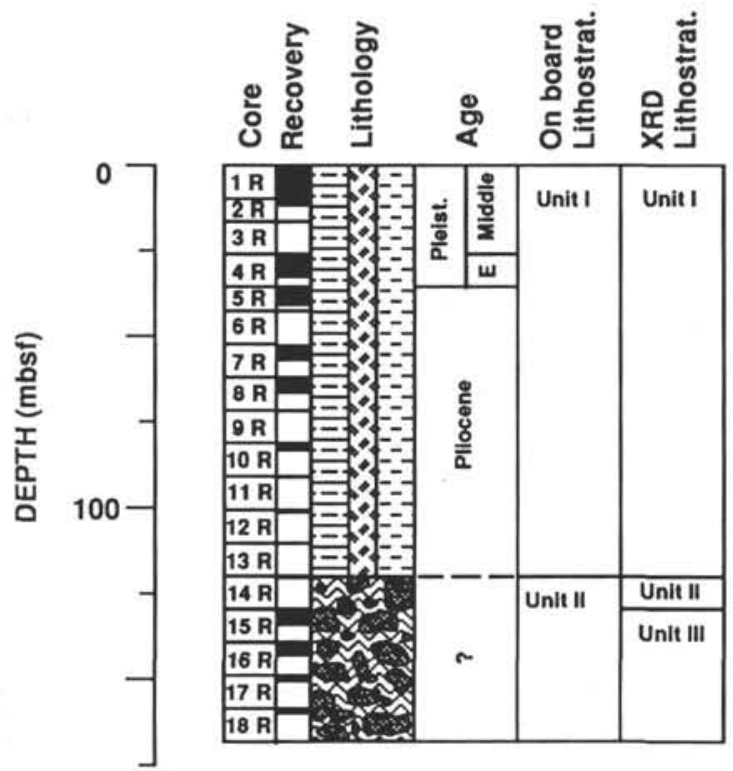

Legend A

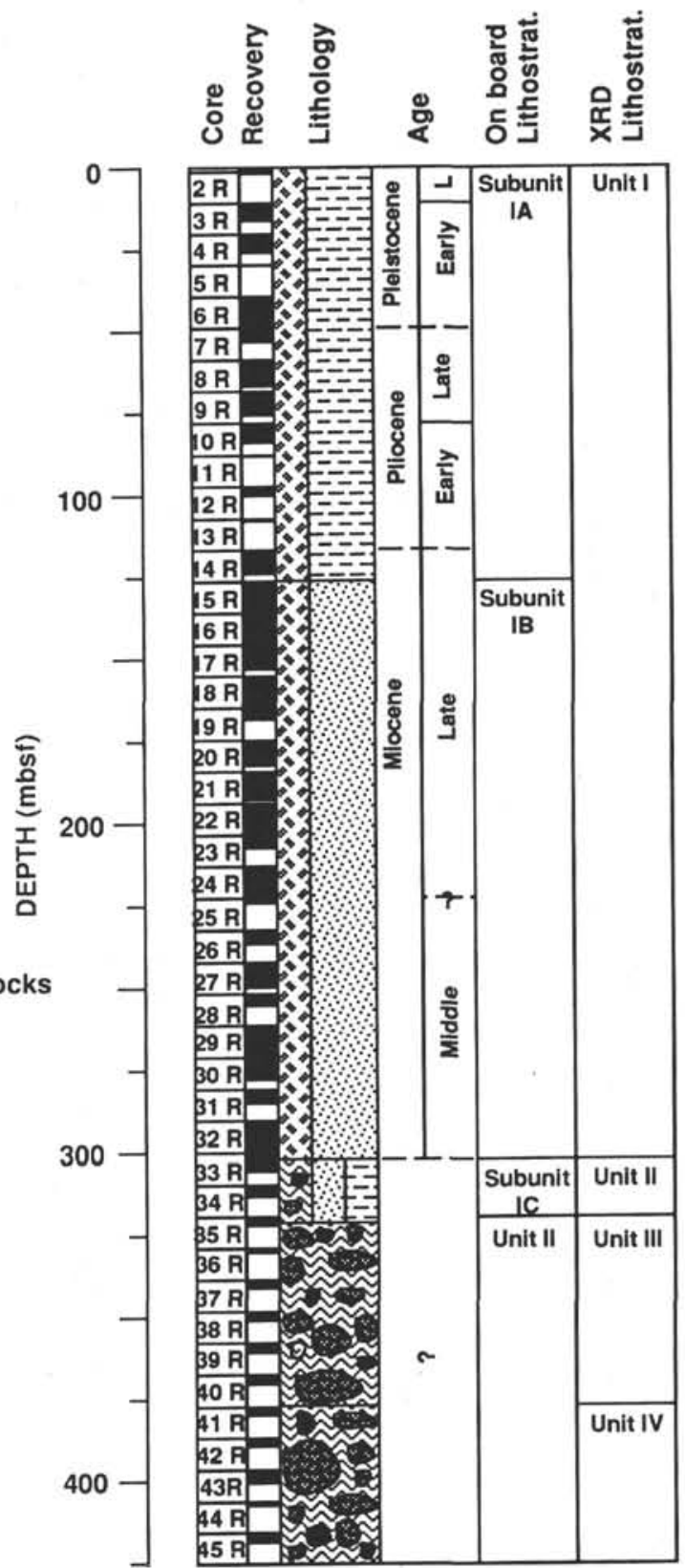

\section{Legend B}

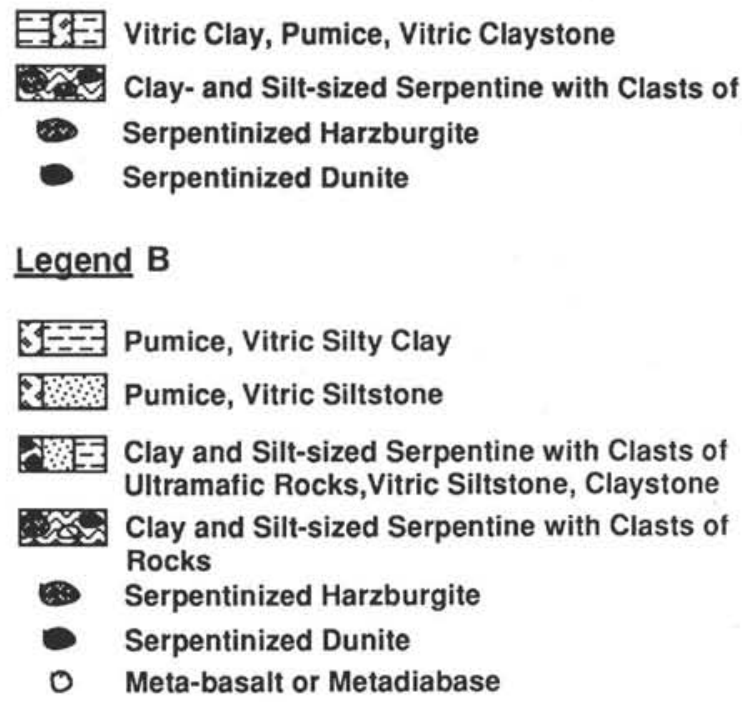

Figure 10. Lithostratigraphic summary of the Torishima Forearc Seamount Holes 783A (A) and 784A (B).

are comparable. If so, despite the possible recovery bias, the relatively lower number of the clasts and the generally smaller size of the clasts from Hole 778A is noteworthy. An examination of the current distribution of flows on the seamount as depicted on the SeaMARC II side-scan image (Fig. 4) suggests a restriction of the most recent flows to the north-south and east-west quadrants of the seamount (Fryer et al., 1990). There is no indication of internal structural control of this distribution (for example, no obvious rift zone structure) based on the existing seismic reflection data collected on surveys of the seamount (Fryer et al., 1990). It is reasonable to speculate that if the current distribution of flows indicates the eruptive pattern followed throughout the seamount's history, then the south flank may have experienced a greater degree of reworking. Such reworking, as a consequence of more frequent eruption-related disturbance, could account for the smaller size of the clasts, the greater degree of roundness of the clasts, and for the wider distribution of the mafic component of the clast population with depth in Hole 778 A than in Hole 779A. Clearly, detailed investigations of the internal structure of the seamount will be required in order to test this hypothesis.

\section{Torishima Forearc Seamount (Sites 783 and 784)}

\section{Lithology}

The stratigraphic section recovered at Site 783 was divided into two lithologic units, based on shipboard observations (Fig. 10A). Unit I contains a vitric clayey silt and glass-rich silty clay or claystone. Unit II, is composed of phacoidal, sheared serpentine that displays convolute bedding and blocks of serpentinized harzburgite. The contact between the lithologic units was not recovered. The oldest age determined from diatom biostratigraphy in Unit I is lower Pliocene. No fossils or 
obvious detrital components were found in Unit II. Thus, the age of these strata is unknown.

The stratigraphic section recovered at Site 784 was divided into two lithologic units (Fig. 10B). Lithologic Unit I consists of ash layers; feldspar- and glass-rich, clayey silt; glass-rich, silty clay/claystone; vitric claystone; claystone; and silt-sized serpentine, and has been divided into three subunits. The deepest of these subunits, Subunit IC from 302.7-321.1 mbsf, in Sections 125-784A-33R-2, $120 \mathrm{~cm}$, to $125-784 \mathrm{~A}-35 \mathrm{R}-2,34 \mathrm{~cm}$, contains the first serpentinebearing muds. Silt-sized serpentine is typically interlayered with claystone. In Section 125-784A-35R-1, from 91 to $121 \mathrm{~cm}$, there is a serpentine breccia composed of $5-\times 6-\mathrm{cm}$, rounded clasts with a faint phacoidal texture and millimeter-sized angular grains. The matrix of this breccia is silt-sized serpentine with variably colored layers. From 121 to $136 \mathrm{~cm}$, in Core 125-784A-35R, rounded millimeter-sized clasts are scattered through a finer, variegated matrix having a sigmoidal deformation pattern. Subunit IC contains no fossils. Thus, no age has been determined for this subunit.

At Site 784, the contact between Lithologic Unit I and Lithologic Unit II, from 321.1 to $425.3 \mathrm{mbsf}$, in Sections 125-784A-35R-2, $34 \mathrm{~cm}$, to $125-784$ A-45R-CC (Fig. 10B), is represented by an abrupt change to sheared, phacoidal, serpentine microbreccia having vertical, convolute deformation. Blocks of serpentinized harzburgite containing a matrix of phacoidal, sheared, serpentine microbreccia appear in Core $125-784 \mathrm{~A}-36 \mathrm{R}$ and continue throughout the remainder of the unit. The presence of Pleistocene nannofossils and siderite (rhodochrosite?) in siltstone indicate downhole contamination at the tops of Cores 125-784A-36R, -37R, -38R, -39R, and -43R. No fossils were found within the phacoidal, sheared, serpentine microbrecia: the age of these strata are therefore unknown. Lithologic Unit II at Site 784 is probably either locally derived from the adjacent topographic high or represents the underlying "acoustic basement" at this site. This unit correlates with Lithologic Unit II at Site 783 on the northern flank of the seamount.

\section{Structures and Physical Characteristics}

The serpentine-mud matrix contains fine sand- to cobble-sized clasts, largely of serpentinized harzburgite. The light blue, light blue-green, light green, to pale yellow-green matrix exhibits anastomosing shear foliation always parallel to the layering and defined by (1) deformed color-banding, (2) the long axes of phacoidal serpentinite fragments, and (3) variations in clast size and concentration.

The phacoids are from one to several centimeters long and from a few millimeters to a few centimeters across. Much of the material between large phacoids consists of smaller phacoids. The foliation is whorled, contorted, and convolute, with foliation streams swirling, branching, and rejoining around the larger clasts, which suggests drilling disturbance.

Phacoids within the matrix typically exhibit pinch-and-swell texture (boudinage) along their long axes and commonly are cut by serpentine veins and/or microfaults at high to moderate angles with respect to their long axes. These microfaults almost universally exhibit a normal sense of movement with respect to the long axes of the phacoids. This texture, together with the boudinage and veining, indicates that the phacoidal matrix has undergone major extension (pure shear) parallel to the layering, foliation, and the direction of alignment of the phacoids. This extension was both brittle and ductile.

Veins are well-developed in some places within the serpentinite muds. The interval at 10 to $20 \mathrm{~cm}$ of Section $125-783 \mathrm{~A}-14 \mathrm{R}-1$ preserves much of the contact between more "normal" pelagic/volcaniclastic sediment, containing about $4 \%$ modal serpentine, and the underlying serpentinite. Interval $125-783 \mathrm{~A}-14 \mathrm{R}-1,13$ to $15 \mathrm{~cm}$, is a serpentinized harzburgite tectonite clast; the interval from 15 to $20 \mathrm{~cm}$ is unfoliated serpentinite mud that contains a well-developed, branching network of cross-fiber serpentine veins up to $3 \mathrm{~mm}$ wide that clearly are growing in the mud. This is important because it provides unambiguous evidence that serpentinization is continuing in the disaggregated, unlithified mud.

Within the sheared, phacoidal serpentinites below this mud, both phacoid and interphacoid material is highly veined with serpentine. Whereas some veins in phacoids end at the phacoid margin, others pass outward into the matrix. Many of these veins have become deformed, drawn out into, and incorporated within the matrix. In at least two intervals (125-783A-18R-1, 76-85 cm, and 100-125 cm) large serpentinite clasts are cut by intricate, anastomosing networks of veins, that pass out into narrow channels of finely phacoidal serpentinite matrix that also cut the clasts. The clasts themselves were quite soft and water-saturated when recovered. These intervals apparently preserve a late stage of the fragmentation of large clasts and show formation of serpentine veins. They also indicate the continuing hydration, softening, and shearing of clasts and incorporation of the clasts into the phacoidal matrix.

The results of rheological studies showed that the sheared, phacoidal serpentinite matrix from Site 783 is weak, and has failure strengths that range between 16 and $51 \mathrm{kPa}$ (Phipps and Ballotti, this volume). These materials are comparable in strength to similar materials recovered from other sites, although they are significantly weaker than the overlying claystones and significantly stronger than the average unfoliated serpentinite at Site 780 (Phipps and Ballotti, this volume). The mode of failure is different from that of samples from Site 780 (Fig. 8). At low strains, the stress-strain curves are much more linear, the strain appears to be more elastic, and the material fails in a brittle manner (Phipps and Ballotti, this volume). These results reflect the greater dewatering and compaction of the Site 783 serpentine than of that on the flanks and summit of Conical Seamount. The Site 783 serpentine is different from the pasty, weak, plastic, littlefoliated serpentinite mud recovered from the shallow levels of Sites 778 and 779 on the flanks of Conical Seamount. At Site 783, pasty, unfoliated serpentinite is restricted to Core 125-783A-14R, at the serpentinite-volcanogenic sediment interface, which is likely to be a zone of extensive fluid transfer and is apparently a zone of active serpentinization (Fryer, Pearce, Stokking, et al., 1990). The sheared, phacoidal serpentinite from Site 783 is also different from the unfoliated serpentinite mud from Site 780, a site of active upwelling of water-charged mud. The serpentine from Site 783 is similar rheologically to that from the deep levels at Sites 778 and 779, both of which have undergone extensive desiccation. The serpentinite at Site 783 is blanketed by virtually serpentine-free sediment which is at least as old as early Pliocene (Fryer, Pearce, Stokking, et al., 1990). Thus, the stratigraphy, sedimentology, paleontology, and rheology of the materials recovered from Site 783 together suggest that serpentinite debris-flow processes were once active, but have since ceased, allowing the serpentinite to be blanketed with pelagic and volcanogenic sediment. Serpentinization and dewatering have continued.

At Site 784, Subunit IC and Unit II contain many types of variably sheared clastic serpentine sediments, similar to those recovered at the previous Sites 778, 779, and 783 (Fryer, Pearce, Stokking, et al., 1990). The serpentine microbreccias characteristic of these units exhibit convolute bedding and plastic folding probably caused by drilling disturbance. Phacoidal, sheared serpentine is abundant. Most of the phacoids are sheared, soft clasts, but some have asymmetrical shapes, suggesting deformation by simple shear.

In Subunit IC, the interlayering of poorly sorted, clastic, serpentine sediments containing coarse angular fragments with better-sorted, finer-grained, volcanogenic/pelagic sediments provides good evidence for interfingering between locally derived serpentine debris 
flows and sediment distally derived from frontal arc volcanoes. The serpentine layers are as thin as $30 \mathrm{~cm}$, and yet contain weakly to well-developed phacoidal textures. Aboard ship, this was interpreted to indicate that the phacoidal texture might have been formed during flow emplacement. Individual layers of serpentine are thinner at Site 784 than at Site 783, or at any of the sites on Conical Seamount, possibly because Site 784 was located farther from the source of the serpentine material, presumed to be Torishima Forearc Seamount. Intervals of clast-supported, matrix-poor breccias, a few tens of centimeters thick, are distinct from the convolute, matrix-rich microbreccias and may represent talus deposits. In-situ serpentinization, hydration, and fragmentation of matrix and clasts may provide a source for the breccias observed.

Rheological studies showed that the average strength of the serpentine muds at Site 784 is $79.1 \mathrm{kPa}$ higher than the maximum strengths at other sites (Phipps and Ballotti, this volume). The greater strength of the Site 784 serpentine muds is attributed to the greater degree of desiccation and lithification of the units as a consequence of their deeper burial and greater age, by comparison with similar units from other sites.

\section{Pore-Water Composition}

By contrast with the pore fluids from Conical Seamount, the composition of pore fluids from the flank sites on Torishima Forearc Seamount, Sites 783 and 784 , are little different from seawater with respect to chloride and bromide. The $\mathrm{pH}$ of the samples is less than 10. Methane content is low, and no higher hydrocarbons were detected in the serpentine mud samples. Relative to seawater, the pore fluids have low alkalinity, sulfate, $\mathrm{K}$, and $\mathrm{B}$, and slightly lower $\mathrm{Rb}$ and $\mathrm{Li}$. They have low $\mathrm{Mg}$ and low $\mathrm{Si}$ relative to seawater, but exhibit relatively little change in $\mathrm{Br}, \mathrm{Na}$, and $\mathrm{Na} / \mathrm{Cl}$. They are enriched in $\mathrm{Ca}$, $\mathrm{Sr}, \mathrm{Ba}$, and ${ }^{34} \mathrm{~S}$. On the basis of these data, the compositions of Site 783 and 784 pore waters do not indicate a deep source (Mottl, this volume; Mottl and Alt, this volume). Rather, the pore waters from Torishima Forearc seamount are examples of seawater interaction with harzburgite at low temperature. If Torishima Forearc Seamount, draped by arc sediments which are at least 10 m.y., was constructed in part by serpentine mud flows containing fluids having a deep source, the pore water data of Mottl (this volume) and Mottl and Alt (this volume) indicate that those deep fluids have since been supplanted by seawater.

Haggerty and Chadhuri (this volume) determined that the average ${ }^{87 / 86} \mathrm{Sr}$ isotopic ratio of the Site 784 pore fluids is 0.70769 $( \pm 0.000010$ ). This value is 0.00155 to 0.00152 lower than the range of values for seawater and suggests the possibility of multiple sources for these interstitial waters (Haggerty and Chadhuri, this volume). Haggerty and Chadhuri (this volume) note that it is difficult to distinguish between the specific igneous source or sources that cause the offset from present-day seawater. A small amount of ethane was detected from one of the samples from the pelagic sediment immediately above the serpentine mud unit at Site 784. This sample was from a section of the sediment that contained water escape structures, leading Haggerty and Chadhuri (this volume) to suspect that the fluids may have derived from the underlying serpentine muds. Following reasoning similar to that which they applied to the Conical Seamount data, they suggest that it is possible that the Torishima Forearc Seamount fluids may involve a subduction-related component.

\section{Petrology}

The rocks retrieved from Torishima Forearc Seamount are primarily harzburgite and dunite (Ishii et al., this volume) that differ little in composition from those of the Mariana forearc samples recovered at Conical Seamount (Fryer, Pearce, Stokking, et al., 1990; Saboda et al., this volume). Minor amounts of metamorphosed basalt were recovered, and one sample of a metavolcaniclastic rock was recovered from each of the holes (Maekawa et al., this volume). No detailed geochemical studies were performed on these samples to determine provenance, nor were detailed microstructure studies performed. The grade of metamorphism of the Torishima Forearc Seamount samples is prehnite-actinolite facies, requiring a low-pressure regime (Maekawa et al., this volume).

\section{DISCUSSION}

The history of the peridotite protolith that gave rise to the serpentine seamounts observed on the Mariana and Izu-Bonin forearcs is best delineated by the combined data from microstructural and compositional analyses. Girardeau and Lagabrielle (this volume) interpreted the events recorded in the microstructures and textures of the peridotites from Conical Seamount in terms of a sequence of structural and metamorphic phenomena: (1) initial formation of the peridotite under high-temperature asthenospheric conditions, such as are prevalent in the upper mantle of most ophiolite complexes (either at mid-ocean ridges or in island-arc regimes), followed by remelting and possible infusion of the peridotite with a fluid phase accompanied by a period of high-temperature, low-stress deformation of the peridotite, either precursory to initiation of convergence, or during proto-arc formation; (2) development of ductile shear zones coeval with a protracted period of retrograde metamorphism; and (3) brittle failure of the metamorphosed peridotite. These events are consistent with models of evolution of forearc regimes in terms of metamorphic and thermal history.

All of the evidence from the vent and pore-fluid studies of Conical Seamount indicate that the hydration of the forearc wedge is facilitated by the escape of fluids from the subducting Pacific Plate. It is possible that infusion of the peridotite with a fluid phase (second part of Event 1) took place after the initiation of subduction as a consequence of processes related to magma genesis in the mantle. It is certain that infusion of the supra-subduction zone with fluids derived from the downgoing oceanic slab facilitated metamorphism of the forearc wedge. Thermal modeling suggests that large regions beneath the Mariana forearc develop the stability conditions for the greenschist and blueschist stability fields as subduction proceeds (Fryer and Fryer, 1987; Fryer et al., 1989). Timing of the metamorphism has not been established by any of the studies of the forearc samples thus far, except in a relative sense (Girardeau and Lagabrielle, this volume). However, on theoretical grounds (Fryer and Fryer 1987; Fryer et al., 1989), the stability conditions for the type of metamorphism that took place in Event 2 develop early in the history of the convergence process. Virtually the whole of the forearc could be metamorphosed within 1 m.y. after initiation of subduction. The mantle and lower crust of the forearc wedge can readily accommodate large volumes of fluids through metamorphic processes from nearly the beginning of subduction.

The capacity for incorporation of large volumes of fluids from the downgoing slab into the metamorphosed forearc wedge provides a possible solution to the enigma of mass balance of subduction constituents in convergence zones. Geochemists have long been concerned with the apparent imbalance between (1) the volume of volatile components presumed to have been added to the mantle wedge above the subduction zone and (2) the volume of volatile components measured from volcanic emanations in the arc and backarc regions of convergent plate margins. We now know that the forearc wedge is capable of incorporating large volumes of fluids from the slab and that direct venting of fluids from the dehydration of the slab is possible. Unfortunately, the proportion of fluids involved in each of these two processes is unknown, and the exact nature of fluid transport within the forearc wedge is poorly understood.

The general lowering of temperature in the forearc, as the gradual overturn of isotherms proceeds during subduction, is well-documented by both theoretical modeling and by the prevalence of blue- 
schist-facies metamorphism in convergent margin regimes. A protracted period of retrograde metamorphism (Event 2) is implicit in the mineralogic and structural characteristics of the peridotites described by Girardeau and Lagabrielle (this volume). This period was suggested by them to represent the record of a single deformation event that began at a high temperature and ended at a low one and that the temperature decrease might indicate decreasing depth. This interpretation is consistent with the suggestion of Ishii et al. (this volume) that peridotite diapirism in a supra-subduction zone setting was the precursor to serpentinization of the peridotite and remobilization of the serpentine bodies to form the seamounts drilled. Alternatively, the decreasing temperature regimes in evolving convergent margins (e.g., Fryer and Fryer 1987) can explain the retrograde metamorphism that Girardeau and Lagabrielle (this volume) observe without demanding a change in depth of the peridotite involved. The rapid lowering of temperatures within the overriding wedge of forearc during the first few hundreds of thousands of years after subduction begins could produce widespread retrograde metamorphic effects in the forearc region, particularly a shift toward blueschist and greenschist facies. In fact, the presence of blueschist minerals in some of the rocks from Conical Seamount (Maekawa et al., this volume) implies that some of the samples from Conical Seamount originated at considerable depth. Ductile deformation of the peridotite (also part of Event 2) during the retrograde metamorphism period may be related to any or all of several possible forearc tectonic processes: subduction-related convection processes, tectonic erosion processes, small-scale plate adjustments within forearc blocks, vertical tectonic motions related to subduction of ocean plate seamounts, or diapirism of serpentinite masses.

The magmatic emplacement of peridotite and subsequent serpentinization as suggested by Girardeau and Lagabrielle (this volume) and particularly by Ishii et al. (this volume) is similar to the emplacement mechanism of alpine serpentine described by Lockwood (1971) as espoused by Benson $(1918)$ and by Hess $(1939,1955)$ in his early papers. More recently field relationships in Columbia (Hess, 1966) and particularly in the Franciscan Formation of California (Dickenson, 1966; Lockwood, 1971; 1972; Coleman, 1957; Carlson, 1984) have convinced many geologists that the mechanism of solid emplacement must account for some of the serpentinites and peridotites of former convergent margin terrains that had previously been interpreted as emplaced magmatically.

Brittle fracture of the metamorphosed peridotite (Event 3) was suggested by Girardeau and Lagabrielle (this volume) to record diapiric rise of a massive body of serpentinite. Alternatively, this type of deformation may take place during faulting at relatively shallow depths (a few kilometers) in the forearc lithosphere, triggering events leading to eruption of fluid-charged serpentine fault gouge entraining fragments of the adjacent metamorphosed country rock. Such emplacement is consistent with a mechanism implied by Lockwood (1972), "The mechanisms which trigger protrusions are unknown, although in an area of subduction faults in the overriding plates are to be expected and may provide protrusion channels." Lockwood (1972) further suggested that "Volatiles from sedimentary rocks undergoing metamorphic dehydration in this zone are likely to be concentrated along faults and may also aid protrusion." Lockwood (1972), stressing the density contrast between serpentinite, especially sheared serpentinite (such as that we observe in the drilled seamounts) and the surrounding oceanic lithosphere, likened the rise of the serpentinite to that of salt diapirism in sedimentary sections.

The problem of sorting out the various physical and theoretical parameters pertaining to the mechanism by which the serpentine is emplaced at the seafloor hinges in part on the concept of diapirism of serpentine in forearc regions. The term "diapirism," with respect to the formation of serpentine seamounts on the Mariana and Izu-Bonin forearcs, has been used in many different ways by various investigators of these seamounts. Diapirism in its broadest sense includes the rise of any gravitationally unstable, mobile material.
Diapirism in the Izu-Bonin forearc region has been suggested to result from several mechanisms. As mentioned above, Ishii et al. (this volume) present a model for formation of the Mariana and Izu-Bonin serpentine seamounts that requires magmatic diapirism of a peridotite body. They suggest that a peridotite body passing through the forearc wedge produces a zone of weakened lithosphere, which serves as a channel for the later passage of subduction-related fluids. The fluids serpentinize the peridotite body and remobilization of the serpentinite at a shallow level results in the formation of the serpentine seamount. Fryer and Fryer (1987) suggested that the ridge of serpentinized peridotite exposed in the outer Izu-Bonin forearc region might result from metamorphic expansion of peridotite at the inner trench wall as a consequence of regional metamorphism. Localized regions of higher degrees of hydration of the forearc peridotite could result in uplift of individual serpentinite seamounts (Fryer and Fryer, 1987). Horine et al. (1990), studying the gravity signature of serpentine seamounts of the Izu-Bonin forearc terrace, suggested a similar origin for the seamounts. They noted, however, that although the seamounts are composed of low-density material, the intervening sedimented basins do not rest on low-density material, which suggests that the low-density serpentinized zones must be limited to the seamounts. They proposed that Torishima Forearc Seamount, and by inference others along the ridge, might form by a multistage process. This process involves initial generation of a conduit for the emplacement and protrusion of a small serpentine diapir, followed by local expansion of the country rock surrounding the conduit as a consequence of continued hydration and serpentinization by fluids emanating from a deep source. Horine et al., (1990) suggested that such a block of uplifted forearc lithosphere constitutes the core of Torishima Forearc Seamount, which was subsequently buried under several hundred meters of serpentine debris and possibly mud flows.

Diapirism in the Mariana forearc region likewise has been suggested to form by several mechanisms. Hussong and Fryer (1981) noted the prevalence of serpentinized peridotite in many of the seamounts on the outer Mariana forearc and suggested diapirism as a mechanism of formation. They did not, however, specify the nature of the diapirism. Bloomer (1982) studied the petrology and morphology of the seamounts in detail and suggested that the serpentinization of the peridotite occurred at depth, and as tectonic erosion of the Mariana forearc toe proceeded, large masses of serpentinite were mobilized and emplaced by rising along deep faults in the forearc. Fryer et al.(1990) suggest that some serpentine seamounts may form as mud volcanoes erupting serpentine muds from a central conduit. The mud volcano type of serpentine seamount requires formation of a localized conduit, possibly by fault movement. Conical Seamount is located along the strike of one of a series of morphological lineaments, probably fault zones trending at an azimuth of $045^{\circ}$ (Fig. 2). In fact, Conical Seamount may be located at the intersection of two or more faults (Fryer and Fryer, 1987; Newsom and Fryer, 1987; Marlow, et al., 1990). It is possible that pulses of eruption of serpentine muds at Conical Seamount are related to the movement of faults underlying the seamount. The muds may be produced as a consequence of the mobilization of fault gouge by the escape of deep-seated fluids along active fault planes. The fluids associated with the serpentine from Conical Seamount contain high concentrations of hydrocarbons. Therefore, it is possible that localized melting of clathrates, possibly in response to faulting, might play a role in the mobilization of the serpentine. Verification of a clathrate-related emplacement mechanism will require more detailed investigation. Regardless of the fluid-related transport mechanism, it is clear that derivation of serpentine fault gouge from different depths during faulting would permit the source materials of flow units to vary in composition corresponding to the region of the fault along which the bulk of the movement takes place. The observed variability of the mineralogy and lithology of the flows might reflect heterogeneities within the forearc lithosphere. For instance, the polymict sequence having inter- 
calated sediment layers observed deep in the holes on the flank of Conical Seamount can be interpreted in two ways. The deposits might represent the consequence of debris flows from nearby fault exposures on the seafloor, as suggested by Lagabrielle et al. (this volume). Alternatively, these deposits might represent a period of low protrusion rate tapping source regions of variable lithologies, as suggested by Fryer and Mottl (this volume).

Although the mud volcano mechanism is a viable one for the formation of serpentine deposits on land, we advise caution in interpretation of serpentine deposits similar to those described from Conical Seamount. There is currently evidence of only two active serpentine mud volcanoes on the Mariana forearc (Fryer et al.,1990). Fryer and Fryer (1987) and Fryer et al. (1990) suggest that other serpentine seamounts may form as horst blocks. One of these horst blocks (Pacman Seamount) has a massive deposit of serpentinite debris on its flank. This deposit is indistinguishable by submersible observations from the older sediment-draped serpentine mud flows of Conical Seamount (Fryer et al., 1990). On a gross morphologic scale, however, it is quite different (Fryer and Fryer, 1987) and is unlikely to have formed as a low-viscosity mud flow. If Torishima Forearc Seamount on the Izu-Bonin forearc terrace has a carapace of serpentine mud flows overlying a more coherent horst block, then it is possible that fault-channeled serpentine mud flows may be generated within horst blocks after uplift. There are probably serpentine seamounts formed by mechanisms from throughout the continuum of the diapir, horst, and mud volcano. From the Mariana forearc observations, it appears that seamounts of dissimilar origins may occur close to each other.

The alternative to the mud volcano or diapir origin of these seamounts requires large scale faulting in the forearc. Exposure of serpentinized peridotite via normal faulting in the Mariana forearc was suggested by Lagabrielle et al. (this volume) as the source of debris deposits forming polymict serpentine breccias in the lower unit of Hole 778A. Similarly, Girardeau and Lagabrielle (this volume) suggested that serpentine bodies might be emplaced as a consequence of faulting associated with forearc rifting. Certainly, large scale faulting is common in the Mariana forearc (Mrozowski et al., 1981; Bloomer and Hawkins 1983: Fryer and Fryer, 1987; Newsom and Fryer, 1987; Johnson and Fryer, 1990; Fryer et al., 1990; Marlow et al., 1990). A region approximately $150 \mathrm{~km}$ long immediately south of Pacman Seamount is composed of several, large, interconnected serpentine seamounts of highly irregular shape (Fig. 2) that are apparently broken by a series of morphological lineaments, oriented at an azimuth of about $045^{\circ}$. This region is apparently an uplifted block of serpentinite that has been internally faulted to create discrete edifices. Although there is no direct evidence to support large-scale lateral movement of blocks within the Mariana forearc, at the latitude of the sites drilled on Leg 125, indications are that such fault-related movements may have acted in the past. The block of forearc lithosphere immediately east of the Conical Seamount sites was sampled during several dredging operations (Johnson and Fryer 1987; Johnson and Fryer, 1990; Johnson et al., 1991). It comprises a block of accreted or of uplifted, formerly trapped oceanic plate (Johnson et al., 1991). In either case, lateral tectonic deformation would be required as an emplacement mechanism.

The metamorphic conditions present in the Mariana and Izu-Bonin forearc wedges permit large scale serpentinization of peridotite within these supra-subduction-zone mantle wedges. The mechanism of emplacement of that serpentinite is probably a function of the local tectonic conditions. Detailed side-scanning sonar and bathymetric mapping studies of the Mariana forearc region, planned by the U.S. Geological Survey for the near future, will be invaluable for providing detailed information about the variations in type and distribution of serpentine seamounts on the Mariana forearc region and for determining the relationships of the seamounts to forearc structures.

\section{CONCLUSIONS}

The major findings of recent research on these seamounts can be summarized as follows:

1. Emplacement of large serpentinite seamounts is a common occurrence in the outer half of the Mariana forearc region and on the ridge that forms the western wall of the Izu-Bonin trench.

2. The formation of the seamounts spans the gamut from end-members that are of two types: (1) edifices that exhibit characteristics of mud volcanoes and are composed of unconsolidated serpentine mud flows that have entrained serpentinized ultramafic and other rock types (Conical Seamount) and (2) horst blocks of serpentinized ultramafics, some of which are partially draped with unconsolidated serpentine slump deposits (Pacman Seamount south of Conical Seamount [Fryer and Fryer, 1987]). Composite seamounts are formed by a combination of both processes (possibly Torishima Forearc Seamount).

3. Tectonic processes on the forearc related to subduction and reorientation of stress fields within the forearc, and possible forearc rifting, are important controls over forearc fracture patterns, which in turn are apparently related to the distribution of serpentinite seamounts (Newsom and Fryer, 1987; Marlow et al., 1990). Tectonic processes also are probably the major controlling factor influencing the periodicity of the protrusion of serpentine mud flows on forearc serpentine seamounts associated with venting of fluids.

4. Fluid flux through the forearc region is generated by compaction, desiccation, and dehydration reactions in the downgoing oceanic slab. The flux is accommodated partly by metamorphism of forearc materials and partly through direct venting of the fluids associated with serpentinite seamounts and possibly with fractures. Geochemical evidence indicates that fluids venting through serpentine mud volcanoes are partly derived from a deep-seated source, most likely the subducted slab. If so, this fluid flux through the Mariana forearc wedge might play a critical role in the evolution of the thermal structure of the forearc wedge. It is possible that the degree of flux channeled by fractures within the outer forearc wedge may create local perturbations of the thermal structure, although there is no direct evidence of this type of flux. A better understanding of the distribution of active venting sites will make it possible to model the thermal structure of the forearc more accurately. Furthermore, an understanding of the nature and volume of the fluid flux through the forearc will permit a more accurate estimation of the geochemical budget of convergent margins associated with interoceanic island arcs that are primarily nonaccretionary.

5. Most active convergent margins can accommodate large quantities of fluids from the subducting slab, and thus develop broad regions of greenschist/blueschist-facies stability fields beneath the entire forearc region (Fryer and Fryer, 1987). Thus, under appropriate tectonic conditions, serpentinite seamounts can be emplaced almost anywhere in a nonaccretionary forearc, yet none show development of serpentinite seamounts on the scale of that in the Mariana and Izu-Bonin systems. One reason for the broad distribution of serpentine seamounts in the Mariana forearc region may relate to the extensive recent vertical tectonic deformation (Hussong and Uyeda, 1981; Fryer and Fryer, 1987) of this forearc. The distribution of the serpentine seamounts on the Izu-Bonin forearc terrace has been attributed to hydration of the outer toe of the overriding plate (Fryer and Fryer, 1987) and to a combination of vertical tectonic processes and eruption of serpentine muds (Horine et al., 1990).

6. There are numerous examples of sedimentary serpentinite deposits around the Pacific, in the Mediterranean, and in Caribbean areas (Lockwood, 1971; 1972). Several of these are similar to the deposits forming on Conical Seamount and represented by the older deposits at Torishima Forearc Seamount. We suggest that Conical 
Seamount may represent a type locality for the study of in-situ formation of mud volcano-type, sedimentary serpentinite bodies, although care must be taken not to generalize the nature of the deposits as related to the formation of the related edifice. The holes drilled on the flanks of Torishima Forearc Seamount demonstrate that serpentinization can continue in situ in serpentine debris deposits.

\section{ACKNOWLEDGMENTS}

The interpretation of the synthesized data has benefited particularly from discussions with M. J. Mottl, S. P. Phipps, P. J. Coleman, and G. J. Fryer. The author thanks R. G. Coleman for his insightful review of the manuscript and thanks J. P. Lockwood both for his suggestions for improvement of the manuscript and for the inspiration to look for evidence of his predicted serpentine protrusions in forearc terranes. The preparation of this manuscript was supported by a grant from the United States Science Advisory Committee of the Joint Oceanographic Institutions Inc. This is SOEST contribution no. 2674, Planetary Geosciences contribution no. 661.

\section{REFERENCES}

Beccaluva, L., Macciotta, G., Savelli, C., Serri, G., and Zeda, O., 1980. Geochemistry and $\mathrm{K} / \mathrm{Ar}$ ages of volcanics dredges in the Philippine Sea (Mariana, Yap, Palau trenches and Parece-Vela Basin). In Hayes, D. E. (Ed.), The Tectonic and Geologic Evolution of Southeast Asian Sea and Islands (Pt. 2). Am. Geophys. Union, Geophys. Monogr. Ser., 23:247-270.

Benson, W. N., 1918. The origin of serpentine, a historical and comparative study. Am. J. Sci., 46:439-460.

Bloomer, S., 1982. Structure and evolution of the Mariana Trench, petrologic and geochemical studies [Ph.D. dissert.]. Univ. Calif., San Diego.

Bloomer, S. H., and Hawkins, J. W., 1983. Gabbroic and ultramafic rocks from the Mariana trench: an island arc ophiolite. In Hayes, D. E. (Ed.), The Tectonic and Geologic Evolution of Southeast Asian Seas and Islands (Pt. 2). Am. Geophys. Union, AGU Monogr. Ser., 27:294-317.

,1987. Petrology and geochemistry of boninite series volcanic rocks from the Mariana trench. Contrib. Mineral. Petrol., 97:361-377.

Brown, G., and Taylor, B., 1988. Sea-floor mapping of the Sumisu Rift, Izu-Ogawawara (Bonin) Island Arc. Chishitsu Chosasho Geppo, 39:23-38.

Carlson, C., 1984. Stratigraphic and structural significance of foliate serpentinite breccias, Wilbur Springs. Soc. Econ. Paleontol. Mineral., Field Trip Guidebook, 3:108-112.

Coleman, R. G., 1957. Mineralogy and petrology of the New Idria district California [Ph.D. dissert.]. Stanford Univ., Stanford. CA

Dickinson, W. R., 1966. Table Mountain serpentinite extrusion in California Coast Ranges. Geol. Soc. Am. Bull., 77:451-472.

Dietrich, V., Emmermann, R., Oberhansli, R., and Puchelt, H., 1978. Geochemistry of basaltic and gabbroic rocks from the west Mariana basin and the Marina trench. Earth. Planet. Sci. Lett., 39:127-144.

Fryer, G. J., Fryer, P., and Saboda, K. L., 1989. Thermal and metamorphic evolution of the Mariana forearc. Eos, 70:1381.

Fryer, P., Ambos, E. L., and Hussong, D. M., 1985. Origin and emplacement of Mariana forearc seamounts. Geology, 13:774-777.

Fryer, P., and Fryer, G. J., 1987. Origins of nonvolcanic seamounts in a forearc environment. In Keating, B., Fryer, P., and Batiza, R. (Eds.), Seamounts, Islands, and Atolls. Am. Geophys. Union, AGU Monogr. Ser., 43:6I-69.

Fryer, P., Haggerty, J. A., Tilbrook, B., Sedwick, P., Johnson, L. E., Saboda, K. L., Newsom, S. Y., Karig, D. E., Uyeda, S., and Ishii, T., 1987. Results of studies of Mariana forearc serpentinite diapirism. Eos, 68:1534.

Fryer, P., Pearce, J. A., Stokking, L. B., et al., 1990. Proc. ODP, Init. Repts., 125: College Station, TX (Ocean Drilling Program).

Fryer, P., Saboda, K. L., Johnson, L. E., Mackay, M. E., Moore, G. F., and Stoffers, P., 1990. Conical seamount: SeaMARC II, Alvin submersible, and seismic reflection studies. In Fryer, P., Pearce, J. A., Stokking, L. B., et al., Proc. ODP, Init. Repts., 125: College Station, TX (Ocean Drilling Program), 69-80.

Haggerty, J. A., 1987a. Cold-water, deep-sea chimneys from the Mariana forearc serpentinite seamounts. Eos, 68:1534. 1987b. Petrology and geochemistry of Neogene sedimentary rocks from Mariana forearc seamounts: implications for emplacement of the seamounts. In Keating, B., Fryer, P., and Batiza, R. (Eds.), Seamounts, Islands, and Atolls. Am. Geophys. Union., AGU Monogr. Ser., 43:175-185.

Hess, H. H., 1939. Island arcs, gravity anomalies and serpentinite intrusions. Internat. Geol. Congr. USSR, 2:263-283.

1955. Serpentines, orogeny and epeirogeny. Spec. Pap.-Geol. Soc. Am., 62:391-409.

, 1966. Caribbean Research Project, 1965, and bathymetric chart. Mem.-Geol. Soc. Am., 98:1-10.

Honza, E., and Tamaki, K., 1985. The Bonin Arc. In Nairn, A.E.M., Stehli, F. G., and Uyeda, S. (Eds.), The Ocean Basins and Margins (Vol. 7): The Pacific Ocean: New York (Plenum), 459-502.

Horine, R. L., Moore, G. F., and Taylor, B., 1990. Structure of the outer Izu-Bonin forearc from seismic-reflection profiling and gravity modeling. In Fryer, P., Pearce, J. A., Stokking, L. B., et al., Proc. ODP, Init. Repts., 125: College Station, TX (Ocean Drilling Program), 81-94.

Hussong, D. M., and Fryer, P., 1982. Structure and tectonics of the Mariana arc and forearc: drilling site selection surveys. In Hussong, D. M., Uyeda, S., et al., Init. Repts. DSDP, 60: Washington (U.S. Govt. Printing Office), 33-44. , 1985. Fore-arc tectonics in the northern Mariana Arc. In Nasu, N., Kobayashi, K., Uyeda, S., et al., (Eds.), Formation of Active Ocean Margins: Tokyo (Terra Sci. Publ.), 273-290.

Hussong, D. M., and Uyeda, S., 1982. Tectonic processes and the history of the Mariana Arc: a synthesis of the results of Deep Sea Drilling Project Leg 60. In Hussong, D. M., Uyeda, S., et al., Init. Repts. DSDP, 60: Washington (U.S. Govt. Printing Office), 909-929.

Hyndman, R. D., and Drury, M. J., 1976. The physical properties of oceanic basement rocks from deep drilling on the Mid-Atlantic Ridge. J. Geophys. Res., 81:4042-4052.

Ishii, T., 1985. Dredged samples from the Ogasawara fore-arc seamount or "Ogasawara paleoland"-"fore-arc ophiolite." In Nasu, N., Kobayashi, K., Kushiro, I., Kagami, H. (Eds.), Formation of Active Ocean Margins: Tokyo (Terra Sci. Publ.), 307-342.

Ishii, T., Kobayashi, K., Shibata, T., Naka, J., Johnson, K., Ikehara, K., Iguchi, M., Konishi, K., Wakita, H., Zhang, F., Nakamura, Y., and Kayane, H., 1985. Description of samples from Ogasawara forearc, Ogasawara Plateau and Mariana Trough during KH84-1 Cruise. In Kobayashi, K. (Ed.), Preliminary Report of the Hakuho Maru Cruise KH84-1. Ocean Res. Inst., Univ. of Tokyo, 86-167.

Johnson, L. E., and Fryer, P., 1988. Oceanic plate material on the Mariana forearc. Eos, 69:1471.

1990. Petrography, geochemistry and petrogenesis of igneous rocks from the outer Mariana forearc. Earth Planet. Sci. Lett., 100:304-316.

Johnson, L. E., Fryer, P., and Ishii, T., 1987. Mariana forearc basement adjacent to serpentinite diapirs. Eos, 1534.

Johnson, L. E., Fryer, P., Taylor, B., Silk, M., Sliter, W. V., Jones, D. L., Itaya, T., and Ishii, T., 1991. New evidence for crustal accretion in the outer Mariana forearc: Cretaceous Radiolarian Cherts and MORB-like lavas. Geology, 19:811-814.

Karig, D. E., 1971. Structural history of the Mariana Island arc system. Geol. Soc. Am. Bull., 82:323-344.

Karig, D. E., and Ranken, D., 1983. Marine geology of the forearc region, southern Mariana island arc. In Hayes, D. E. (Ed.), The Tectonic and Geologic Evolution of Southeast Asian Seas and Islands (Pt. 2). Am. Geophys. Union, AGU Monogr. Ser., 23:266-280.

Klein, G. deV., and Kobayashi, K., 1980. Geological summary of the North Philippine Sea based on Deep Sea Drilling Project Leg 58 results. In Klein, G. deV., and Kobayashi, K., et al., Init. Repts. DSDP, 58: Washington (U.S. Govt. Printing Office), 951-962.

Kulm, L. D., et al., 1986. Oregon subduction zone: venting, fauna, and carbonates. Science, 231:561-566.

Leg 125 Scientific Drilling Party, 1990. Plumbing the Pacific sinks. Nature, $339: 427-428$

Leg 125 Shipboard Scientific Party, 1989. ODP Leg 125 drills forearc crust, mantle. Geotimes, 34:18-20.

Lewis, S. D., Hayes, D. E., and Mrozowski, C. L., 1982. The origin of the West Philippine Basin by interarc spreading. In Balce, G. R., and Zanoria, A. S. (Eds.), Geology and Tectonics of the Luzon-Marianas Region. Philippine Seatar Comm. Spec. Publ., 1:31-51.

Lockwood, J. P., 1971. Sedimentary and gravity slide emplacement of serpentinite. Geol. Soc. Am. Bull., 82:919-936. 
1972. Possible mechanisms for the emplacement of alpine-type serpentinite. Mem. Geol. Soc. Am., 132:273-287.

Marlow, M. S., Merrill, D. L., and Shipboard Scientific Party, 1990. Underway geophysics. In Fryer, P., Pearce, J. A., et al., Proc. ODP, Init. Repts., 125: College Station, TX (Ocean Drilling Program), 41-67.

Meijer, A., 1980. Primitive arc volcanism and a boninite series: examples from the western Pacific island arc system. In Hayes, D. E. (Ed.), Tectonic and Geologic Evolution of Southwest Asian Seas and Islands. Am. Geophys. Union, Geophys. Monogr. Ser., 23:269-282.

Mrozowski, C. L., Hayes, D. E., and Taylor, B., 1981. Multichannel seismic reflection surveys of Leg 60 sites, Deep Sea Drilling Project. In Hussong, D. M., Uyeda, S., et al., Init. Repts. DSDP, 60: Washington (U.S. Govt. Printing Office), 57-71.

Newsom, S. Y., and Fryer, P., 1987. Three-dimensional gravity modeling of serpentinite seamounts in the Mariana forearc. Eos, 68:1534.

Saboda, K. L., Fryer, P., and Fryer, G. J., 1987. Preliminary studies of metamorphic rocks collected during Alvin studies of Mariana forearc seamounts. Eos, 68:1534

Schomo, K. S., 1982. Geochemistry of carbon, International Phase of Ocean Drilling Project 60. In Hussong, D. M., and Uyeda, S., et al., Init. Repts. DSDP, 60: Washington (U.S. Govt. Printing Office), 501-504.

Scott, R. B., Kroenke, L. W., Zakariadze, G., et al., 1980. Evolution of the South Philippine Sea: Deep Sea Drilling Project Leg 59 results. In
Kroenke, L., Scott, R., et al., Init. Repts. DSDP, 59: Washington (U.S. Govt. Printing Office), 803-815.

Shih, T., 1980. Marine magnetic anomalies from the western Philippine Sea: implications for the evolution of marginal basins. In Hayes, D. E. (Ed.), The Tectonic and Geologic Evolution of Southeast Asian Seas and Islands (Pt. 2). Am. Geophys. Union, AGU Monogr. Ser., 23:49-75.

Skornyakova, N. S., and Lipkina, M. I., 1976. Basic and ultrabasic rocks of the Marianas Trench. Oceanology, 15:688-690.

Uyeda, S., and Ben-Avraham, Z., 1972. Origin and development of the Philippine Sea. Nature, 240:176-178.

Wood, D. A., Marsh, N. G., Tarney, J., Joron, L. J., Fryer, P., and Treuil, M., 1982. Geochemistry of igneous rocks recovered from a transect across the Mariana Trough, arc, fore-arc, and trench, Sites 453 through 461, Deep Sea Drilling Project Leg 60. In Hussong, D. M., Uyeda, S., et al., Init. Repts. DSDP, Washington (U.S. Govt. Printing Office), 611-645.

Date of initial receipt: 5 March 1991

Date of acceptance: 12 November 1991

Ms 125B-168 